\title{
Assessment of hydrological pathways in East African montane catchments under different land use
}

\author{
Suzanne R. Jacobs ${ }^{1,2,3,4}$, Edison Timbe ${ }^{5}$, Björn Weeser ${ }^{1,2}$, Mariana C. Rufino ${ }^{4,6}$, Klaus Butterbach-Bahl ${ }^{3,7}$, and \\ Lutz Breuer ${ }^{1,2}$ \\ ${ }^{1}$ Centre for International Development and Environmental Research (ZEU), Justus Liebig University, \\ Senckenbergstr. 3, 35390 Giessen, Germany \\ ${ }^{2}$ Institute for Landscape Ecology and Resources Management (ILR), Justus Liebig University, Heinrich-Buff-Ring 26, \\ 35392 Giessen, Germany \\ ${ }^{3}$ Karlsruhe Institute of Technology, Institute of Meteorology and Climate Research, Atmospheric Environmental Research \\ (KIT/IMK-IFU), Kreuzeckbahnstr. 19, 82467 Garmisch-Partenkirchen, Germany \\ ${ }^{4}$ Centre for International Forestry Research (CIFOR), c/o World Agroforestry Centre, United Nations Avenue, \\ Gigiri, P.O. Box 30677, 00100 Nairobi, Kenya \\ ${ }^{5}$ Facultad de Ciencias Agropecuarias, Carrera de Ingeniería Agronómica, Universidad de Cuenca, \\ Cuenca 010111, Ecuador \\ ${ }^{6}$ Lancaster Environment Centre, Lancaster University, Lancaster LA1 4YQ, UK \\ ${ }^{7}$ Mazingira Centre, International Livestock Research Institute (ILRI), P.O. Box 30709, 00100 Nairobi, Kenya
}

Correspondence: Suzanne R. Jacobs (suzanne.r.jacobs@zeu.uni-giessen.de)

Received: 8 February 2018 - Discussion started: 13 February 2018

Revised: 6 September 2018 - Accepted: 7 September 2018 - Published: 27 September 2018

\begin{abstract}
Conversion of natural forest (NF) to other land uses could lead to significant changes in catchment hydrology, but the nature of these changes has been insufficiently investigated in tropical montane catchments, especially in Africa. To address this knowledge gap, we aimed to identify stream water (RV) sources and flow paths in three tropical montane sub-catchments $\left(27-36 \mathrm{~km}^{2}\right)$ with different land use (natural forest, NF; smallholder agriculture, SHA; and commercial tea and tree plantations, TTP) within a $1021 \mathrm{~km}^{2}$ catchment in the Mau Forest complex, Kenya. Weekly samples were collected from stream water, precipitation (PC) and mobile soil water for 75 weeks and analysed for stable isotopes of water $\left(\delta^{2} \mathrm{H}\right.$ and $\left.\delta^{18} \mathrm{O}\right)$ for mean transit time (MTT) estimation with two lumped parameter models (gamma model, GM; and exponential piston flow model, EPM) and for the calculation of the young water fraction. Weekly samples from stream water and potential endmembers were collected over a period of 55 weeks and analysed for $\mathrm{Li}, \mathrm{Na}, \mathrm{Mg}, \mathrm{K}, \mathrm{Rb}, \mathrm{Sr}$ and $\mathrm{Ba}$ for endmember mixing analysis (EMMA). Solute concentrations in precipitation were lower than in stream water in all catchments
\end{abstract}

$(p<0.05)$, whereas concentrations in springs, shallow wells and wetlands were generally more similar to stream water. The stream water isotope signal was considerably damped compared to the isotope signal in precipitation. Mean transit time analysis suggested long transit times for stream water (up to 4 years) in the three sub-catchments, but model efficiencies were very low. The young water fraction ranged from $13 \%$ in the smallholder agriculture sub-catchment to $15 \%$ in the tea plantation sub-catchment. Mean transit times of mobile soil water ranged from 3.2-3.3 weeks in forest soils and 4.5-7.9 weeks in pasture soils at $15 \mathrm{~cm}$ depth to 10.4-10.8 weeks in pasture soils at $50 \mathrm{~cm}$ depth. The contribution of springs and wetlands to stream discharge increased from a median of 16.5 (95\% confidence interval: 11.3-22.9), $2.1(-3.0-24.2)$ and $50.2(30.5-65.5) \%$ during low flow to 20.7 (15.2-34.7), 53.0 (23.0-91.3) and 69.4 (43.0-123.9) \% during high flow in the natural forest, smallholder agriculture and tea plantation sub-catchments, respectively. Our results indicate that groundwater is an important component of stream water, irrespective of land use. The results further suggest that the selected transit time models and tracers 
might not be appropriate in tropical catchments with highly damped stream water isotope signatures. A more in-depth investigation of the discharge dependence of the young water fraction and transit time estimation using other tracers, such as tritium, could therefore shed more light on potential land use effects on the hydrological behaviour of tropical montane catchments.

\section{Introduction}

Tropical montane forests are under high anthropogenic pressure through deforestation. Evidence from tropical montane regions in Central and South America shows that conversion of montane forests to pastures increases the contribution of surface run-off to streamflow, caused by changes in flow paths and stream water (RV) sources (Ataroff and Rada, 2000; Germer et al., 2010; Muñoz-Villers and McDonnell, 2013). This could affect the timing and quantity of the water supply through reduced infiltration of precipitation (PC) and increased occurrence of flood events and could reduce water quality as a result of soil erosion. In Africa, where much of the population relies on surface water as the main water source, understanding the effect of land use change on water supply and quality is crucial to manage resources sustainably. However, the hydrological functioning of tropical catchments is generally less well understood than that of temperate catchments. This is specifically true for tropical montane forest catchments, as those have received less attention in hydrological research compared to the tropical lowlands.

Several studies investigated the hydrological functioning of tropical montane catchments in Latin America (e.g. Correa et al., 2017; Crespo et al., 2012; Mosquera et al., 2016b; Roa-García and Weiler, 2010; Timbe et al., 2014; Windhorst et al., 2014). These studies highlight the importance of soil and groundwater as source of stream water, as both Andean Páramo catchments and tropical montane cloud forest catchments showed a high contribution of pre-event water to streamflow (Correa et al., 2017; Crespo et al., 2012; Mosquera et al., 2016a). Land use change could, however, affect the relative contribution of different water sources and flow paths. Pasture catchments showed, for example, a higher contribution of event water to streamflow compared to forest catchments in the Amazon (Chaves et al., 2008; Neill et al., 2011) and shorter transit times than montane forest catchments in Mexico and the Ecuadorian Andes (MuñozVillers et al., 2016; Timbe et al., 2014). Furthermore, montane catchments in the Colombian Andes showed a faster response to events in catchments with a higher grassland cover than in catchments with a higher forest cover (Roa-García and Weiler, 2010). In contrast, Crespo et al. (2012) found that montane catchments in the Ecuadorian Andes were dominated by deep groundwater, irrespective of topography or land cover. Differences in climate, land use types, topography and geology limit the potential to extrapolate the results obtained from studies in Latin America to other tropical montane catchments. This highlights the need for research on hydrological processes in relation to land use in less-studied regions, such as East Africa, where population growth puts significant pressure on forests and water resources, but where little is known about the consequences of deforestation for water supply and quality.

The Mau Forest complex in western Kenya is the largest tropical montane rainforest in the country and considered a major "water tower", supplying fresh water to approximately 5 million people living downstream (Kenya Water Towers Agency, 2015). However, conversion of forest to agricultural land resulted in a $25 \%$ forest loss in the past decades (Kinyanjui, 2011). This has supposedly led to changes in flow regime (Baldyga et al., 2004; Mango et al., 2011; Mwangi et al., 2016) and increased surface run-off (Baker and Miller, 2013). This suggests that changes in dominant flow paths occurred as a consequence of land use change, but no scientific evidence is available to confirm this. In this study, we used a combination of mean transit time (MTT) analysis and endmember mixing analysis (EMMA) to assess the effect of land use on spatial and temporal dynamics of water sources and flow paths in catchments with contrasting land use (i.e. natural forest, NF; smallholder agriculture, SHA; and commercial tea and tree plantations, TTP) in the Mau Forest complex. Mean transit time, i.e. the time required for rainfall to reach the stream, is a good indicator to assess flow paths, water storage capacity and mixing at the catchment scale (Asano and Uchida, 2012). Since MTT can be influenced by catchment characteristics that are often affected by land use, such as soil cover (Capell et al., 2012; Rodgers et al., 2005; Soulsby et al., 2006) and soil hydraulic properties (Heidbüchel et al., 2013; Mosquera et al., 2016b; MuñozVillers et al., 2016), MTT is a useful indicator to assess the effect of land use on hydrological processes. A quantification of the contribution of different endmembers or water sources in a catchment, through the application of EMMA, provides relevant insight into dominant flow paths and stream water sources (Barthold et al., 2010; Burns et al., 2001; Correa et al., 2017; Crespo et al., 2012; Soulsby et al., 2003) or water provenance (Fröhlich et al., 2008a, b). Previous studies have shown the advantage of combining the two approaches to improve the understanding of hydrological systems (Crespo et al., 2012; Katsuyama et al., 2009).

We used stable isotopes of water $\left({ }^{2} \mathrm{H}\right.$ and $\left.{ }^{18} \mathrm{O}\right)$ and trace element data collected over a 55 to 75 week period in the South-West Mau block of the Mau Forest complex to assess water provenance and flow paths in three sub-catchments, dominated by either natural forest, smallholder agriculture, or tea and tree plantations. Earlier studies in the South-West Mau observed reduced infiltration rates in agricultural compared to forested land use types (Owuor et al., 2018). Furthermore, analysis of nitrate concentration-discharge rela- 
tionships of rainfall events suggested more surface run-off in catchments dominated by smallholder agriculture or commercial tea and tree plantations than in a montane forest catchment (Jacobs et al., 2018). Based on these results, we hypothesized that (a) the natural forest sub-catchment has a longer MTT than the tea plantation and the smallholder agriculture sub-catchments, because precipitation contributes less to streamflow in the forest catchment, and (b) the precipitation that contributes directly to streamflow will reach the stream through surface run-off in the tea plantation and smallholder agriculture sub-catchments and through shallow subsurface flow in the forest sub-catchment.

\section{Methods}

\subsection{Study area}

This study was conducted in the South-West Mau block of the Mau Forest complex, western Kenya (Fig. 1, Table 1). Three sub-catchments $\left(27-36 \mathrm{~km}^{2}\right)$ were characterized by different land use types: natural forest, smallholder agriculture, and commercial tea and tree plantations. These were nested in a $1021 \mathrm{~km}^{2}$ large catchment, referred to as the main catchment (OUT), which was characterized by a mixture of these three land use types $(\mathrm{NF}=37.6 \%, \mathrm{SHA}=51.0 \%$ and TTP $=11.4 \%$ ). The natural forest is classified as an Afromontane mixed forest, with species including Podocarpus milanjianus, Juniperus procera and Olea hochstetteri (Kinyanjui, 2011; Krhoda, 1988). The vegetation transitions into bamboo forest, characterized by Arundinaria alpina, above $2300 \mathrm{~m}$ elevation. The north-western side of the forest, bordering smallholder agriculture, is degraded through the encroachment of farms, livestock grazing, charcoal burning and logging (Bewernick, 2016). The smallholder agriculture area is characterized by small farms of less than 2 ha, where beans, maize, cabbage and potatoes are grown interspersed with grazing fields for livestock and small wood lots of Eucalyptus, Pinus and Cupressus spp. The riparian zones are severely degraded by vegetation clearance for grazing or cultivation and access to the river by humans and livestock. Commercial tea plantations, covering approximately $20000 \mathrm{ha}$, are found at lower elevation (1700-2200 m) closer to Kericho town $\left(0^{\circ} 22^{\prime} 08^{\prime \prime} \mathrm{S}, 35^{\circ} 17^{\prime} 10^{\prime \prime} \mathrm{E}\right)$ and consist of a mosaic of tea fields and Eucalyptus plantations, the latter mainly being used for tea processing. Riparian forests of up to $30 \mathrm{~m}$ width are well maintained and contain native tree species, such as Macaranga kilimandscharica, Polyscias kikuyuensis, Olea hochstetteri and Casearia battiscombei (Ekirapa and Shitakha, 1996). A more detailed description of land use in the study area can be found in Jacobs et al. (2017).

The geology in OUT originates from the early Miocene, with the lower part, encompassing NF and TTP, dominated by phonolites and the upper part, covering SHA, by phonolitic nephelinites with a variety of Tertiary tuffs (Binge, 1962;
Jennings, 1971). The soils are deep and well drained, classified as humic Nitisols (ISRIC, 2007; Krhoda, 1988). The area has a bimodal rainfall pattern with highest rainfall between April and July (long rains) and October and December (short rains). January to March are the driest months. Long-term annual precipitation at $2100 \mathrm{~m}$ elevation is $1988 \pm 328 \mathrm{~mm} \mathrm{yr}^{-1}$ (Jacobs et al., 2017).

\subsection{Hydroclimatic instrumentation}

Hydroclimatic data have been measured in the study area since October 2014 at a $10 \mathrm{~min}$ interval (Jacobs et al., 2018). Water level data were recorded at the outlet of each catchment with a radar-based sensor (VEGAPULS WL61, VEGA Grieshaber KG, Schiltach, Germany). Discharge was estimated from these data using a site-specific second-order polynomial rating curve (Jacobs et al., 2018). Nine tipping bucket rain gauges (Theodor Friedrichs, Schenefeld, Germany, and ECRN-100 high-resolution rain gauge, Decagon Devices, Pullman WA, USA) were installed in the study area across an elevation gradient of 1717 to $2602 \mathrm{~m}$ (Fig. 1). Each tipping bucket recorded cumulative precipitation (resolution of $0.2 \mathrm{~mm}$ per tip) per $10 \mathrm{~min}$. Precipitation in each catchment was calculated using Thiessen polygons.

\subsection{Sampling and laboratory analysis}

Each catchment had one site with a precipitation and throughfall (TF) sampler, constructed of a $1 \mathrm{~L}$ glass bottle covered with aluminium foil and a funnel of $12.5 \mathrm{~cm}$ diameter with a table tennis ball to reduce sample fractionation due to evaporation (Windhorst et al., 2013). The throughfall sampler was placed inside the forest, underneath maize or sugar cane (depending on growing season) and underneath tea bushes in NF, SHA and TTP, respectively. The main catchment only had a precipitation sampler. Additionally, a passive capillary wick sampler was installed in each catchment to collect mobile soil water (Brown et al., 1989). Three polythene plates of 30 by $30 \mathrm{~cm}$ were inserted horizontally at 15,30 and $50 \mathrm{~cm}$ depth in the soil with as little disturbance of the soil above and around the plate as possible. A glass fibre wick was unravelled and draped on top of each plate to maximize surface area. The remaining wick length was led through a hosepipe to a $1 \mathrm{~L}$ glass bottle, which was placed at 1 to $1.5 \mathrm{~m}$ depth in the soil. The installation of all samplers was carried out in September 2015 and samples were collected from 15 October 2015 to 17 March 2017. Stream water samples were taken at the outlet of all catchments on a weekly basis. The samples were filtered with $0.45 \mu \mathrm{m}$ polypropylene filters (Whatman Puradisc 25 syringe filter, GE Healthcare, Little Chalfont, UK, or KX syringe filter, Kinesis Ltd, St Neots, UK) and stored in $2 \mathrm{~mL}$ glass vials with a screw cap. Weekly integrated samples were collected from the wick, precipitation and throughfall samplers. The samples were analysed for isotopic composition in the labora- 
Table 1. Physical and hydroclimatic characteristics of the study catchments in the South-West Mau, Kenya. Precipitation, specific discharge and run-off ratio are presented for the study period of 15 October 2015 to 14 October 2016.

\begin{tabular}{lrrrrrr}
\hline Catchment & $\begin{array}{r}\text { Area } \\
\mathrm{km}^{2}\end{array}$ & $\begin{array}{r}\text { Elevation } \\
m\end{array}$ & $\begin{array}{r}\mathrm{Slope}^{\mathrm{a}} \\
\%\end{array}$ & $\begin{array}{r}\text { Precipitation } \\
\mathrm{mm} \mathrm{yr}^{-1}\end{array}$ & $\begin{array}{r}\text { Specific discharge } \\
\mathrm{mm} \mathrm{yr}^{-1}\end{array}$ & $\begin{array}{r}\mathrm{RR}^{\mathrm{b}} \\
-\end{array}$ \\
\hline Natural forest (NF) & 35.9 & $1954-2385$ & $15.5 \pm 8.0$ & 2299 & 744 & 0.323 \\
Smallholder agriculture (SHA) & 27.2 & $2380-2691$ & $11.5 \pm 6.5$ & 1738 & 607 & 0.349 \\
Tea and tree plantations (TTP) & 33.3 & $1786-2141$ & $12.2 \pm 7.3$ & 2045 & 791 & 0.387 \\
Main catchment (OUT) & 1021.3 & $1715-2932$ & $12.8 \pm 7.7$ & 2019 & 701 & 0.347 \\
\hline
\end{tabular}

${ }^{a}$ Mean \pm SD. ${ }^{b}$ Run-off ratio, i.e. ratio of specific discharge to precipitation.

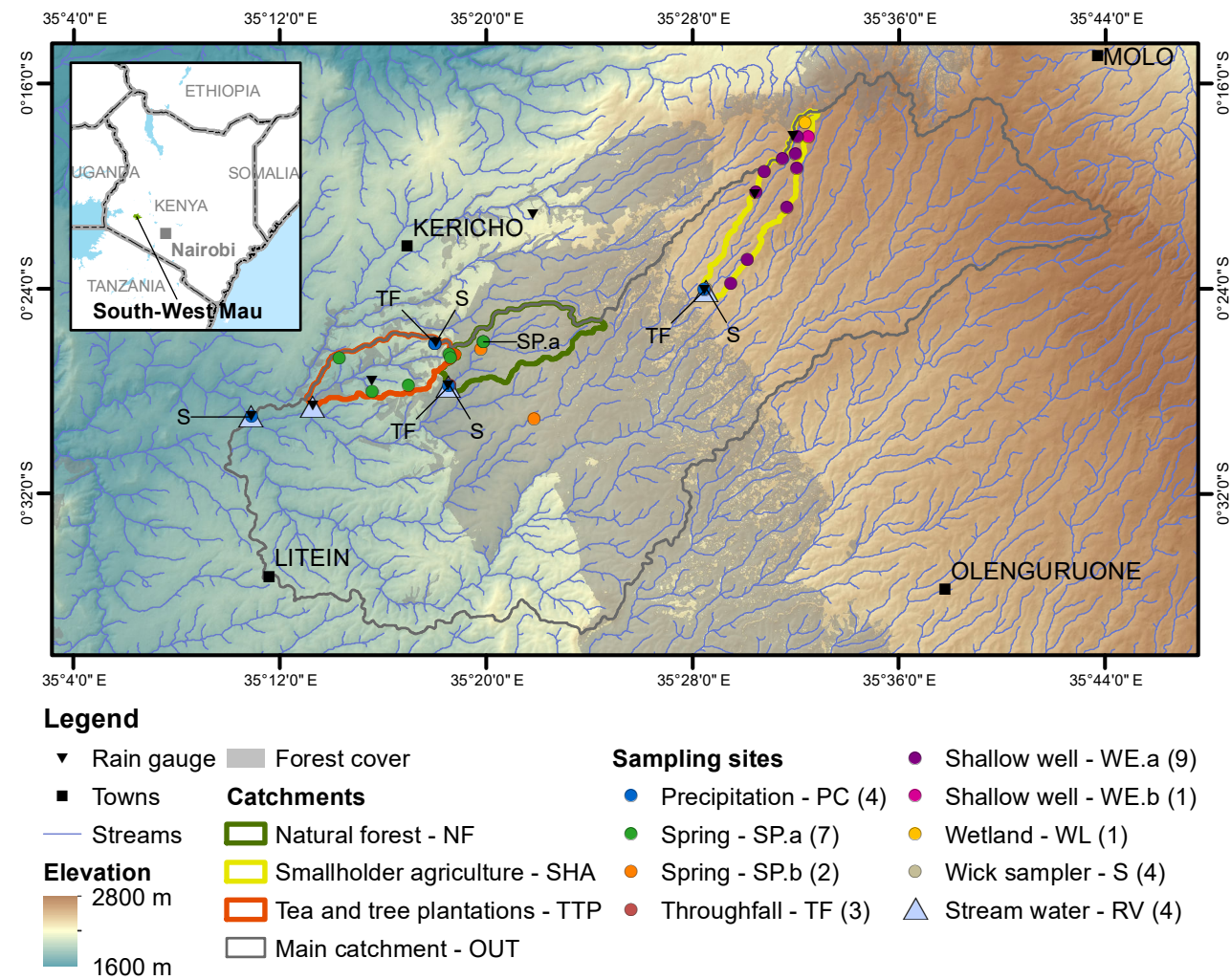

Figure 1. Map of the study area in the South-West Mau, Kenya, showing the three sub-catchments with different land use types within the main catchment, location of rain gauges, and sampling sites for stream water and selected endmembers. Sampling sites with overlapping symbols are indicated with labels instead of symbols. Numbers in brackets in the legend indicate the number of sampling sites per endmember.

tory of Justus Liebig University Giessen, Germany, with cavity ring-down spectroscopy (Picarro, Santa Clara CA, USA). Precipitation water samples from all four sites were used to calculate the local meteoric water line (LMWL) with a linear regression model and the $95 \%$ confidence interval was estimated for the slope and intercept. Only samples with a sampling volume of more than $100 \mathrm{~mL}$ were included to avoid the effect of evaporative enrichment of small sample volumes stored in the collector over the period between sample collections (Prechsl et al., 2014). A linear regression model was also used to assess the effect of elevation on isotope signatures.
For endmember mixing analysis, samples were filtered with $0.45 \mu \mathrm{m}$ polypropylene filters and collected in highdensity polyethylene (HDPE) bottles $(25-30 \mathrm{~mL})$ with a screw cap. Samples were immediately acidified to $\mathrm{pH}<2$ with nitric acid and stored frozen until analysis for trace elements $\mathrm{Li}, \mathrm{Na}, \mathrm{Mg}, \mathrm{Al}, \mathrm{Si}, \mathrm{K}, \mathrm{Ca}, \mathrm{Cr}, \mathrm{Fe}, \mathrm{Cu}, \mathrm{Zn}, \mathrm{Rb}, \mathrm{Sr}, \mathrm{Y}$, $\mathrm{Ba}, \mathrm{Ce}, \mathrm{La}$ and $\mathrm{Nd}$ with inductively coupled plasma mass spectrometry (ICP-MS) in the laboratory of Justus Liebig University Giessen, Germany ( $n=122)$, or the University of Hohenheim, Germany $(n=231)$. At the University of Hohenheim, samples were analysed for $\mathrm{Al}, \mathrm{Ca}, \mathrm{K}, \mathrm{Mg}, \mathrm{Na}$ and $\mathrm{Si}$ with inductively coupled plasma optical emission spec- 
trometry (ICP-OES) instead of ICP-MS. Samples with values below the limit of quantitation (Table S1 in the Supplement) were excluded. Differences in solute concentration between endmembers within each catchment and between catchments were assessed using the non-parametric KruskalWallis test and Conover-Iman post hoc test. Samples for EMMA were collected between 15 October 2015 and 21 October 2016. Weekly samples were taken for stream water, while precipitation and throughfall were sampled approximately every 4-6 weeks $(n=9-11)$. Due to difficult access to sampling sites, other potential water sources were sampled less frequently: wetland SHA-WL $(n=4)$ and spring NF-SP.b $(n=3)$. Springs NF-SP.a and TTP-SP.a were a combination of samples taken at different locations rather than different points in time with $n=2$ and $n=5$, respectively. Ten shallow wells (nine named SHA-WE.a and one SHAWE.b) in SHA were sampled twice. Initially all samples for this endmember were combined, but SHA-WE.b showed a strongly different chemical composition than the other samples and was therefore treated as a separate endmember. No separate endmember sampling was carried out for OUT, except for one spring sample and regular precipitation samples. Since all endmembers from the sub-catchments were sampled within OUT, these endmembers were used to identify potential stream water sources for OUT. It was not possible to use samples collected from the wick samplers for EMMA, because the glass fibre wick could have contaminated the samples and the sample volume was generally too low $(<25 \mathrm{~mL})$. All data are available in the online database for the South-West Mau (Mau Earth Observatory, 2018).

\subsection{Endmember mixing analysis}

In EMMA, stream water is assumed to be a mixture of different endmembers or water sources, such as precipitation, throughfall, groundwater and soil water (Christophersen et al., 1990). The EMMA was carried out following the procedures described in Christophersen and Hooper (1992) and Hooper (2003). The final set of solutes to be included in the EMMA was selected based on conservative behaviour of the solutes, which was assessed with bivariate scatter plots of all possible solute combinations, including stable isotopes of water. A solute was considered conservative when it showed at least one significant $(p<0.01)$ linear relationship with another solute with $R^{2}>0.5$ (Hooper, 2003; James and Roulet, 2006). Principle component analysis was applied to the selected solutes to identify a mixing space that explained most of the variation in stream water solute concentrations. The relative root mean square error (RRMSE) was calculated based on the measured and projected stream water concentrations for the selected solutes for up to four dimensions (i.e. principal components in EMMA). This was used in combination with residual analysis (Hooper, 2003) and the "rule of one" (last included dimension needs to explain at least $1 / n$th of the variation, where $n$ is the number of solutes included in the analysis) to assess how many dimensions $(d)$ should be included in the analysis. Median endmember concentrations were projected in the $d$-dimensional mixing space of the stream water samples of the respective catchments and the $d+1$ endmembers enclosing most of the stream water samples in this mixing space were selected for EMMA. Then, contributions of each endmember to streamflow were calculated. Although it is common practice to project stream water samples that fall outside the triangle enclosed by the three selected endmembers back into the mixing space to constrain endmember contributions to a range of $0 \%$ to $100 \%$, we decided to omit this step as it is indicative of uncertainty in the analysis caused by uncertainty in field and laboratory analyses, non-conservative solute behaviour, unidentified endmembers and temporal variability of endmembers (Barthold et al., 2010). To quantify the uncertainty in endmember contributions, we used a Monte Carlo approach, whereby the EMMA was performed $10^{4}$ times for every stream water sample in each catchment. For each simulation, the input values for the three selected endmembers were sampled randomly using bootstrapping. The 5 th and 95 th percentile were then calculated from the simulations and presented as the uncertainty range.

\subsection{Mean transit time analysis}

Preliminary estimations of mean transit times (MTTs) of stream and mobile soil water were obtained through lumped parameter models. In this approach, the transport of a tracer through a catchment is expressed mathematically by a convolution integral (Maloszewski and Zuber, 1982) in which the composition of the outflow (e.g. stream or mobile soil water) $C_{\text {out }}$ at a time $t$ (time of exit) consists of a tracer $C_{\text {in }}$ that falls uniformly on the catchment in a previous time step $t^{\prime}$ (time of entry). $C_{\text {in }}$ becomes lagged according to its transit time distribution $g\left(t-t^{\prime}\right)$. Having in mind that the time span $t-t^{\prime}$ is in fact the tracer's transit time $\tau$, the convolution integral could be expressed as Eq. (1), in which $g(\tau)$ is the weighting function (i.e. the tracer's transit time distribution, TTD) that describes the normalized distribution of the tracer added instantaneously over an entire area (McGuire and McDonnell, 2006).

$C_{\text {out }}(t)=\int_{0}^{\infty} C_{\text {in }}(t-\tau) g(\tau) d \tau$

The isotopic composition of precipitation was used as input, while stream water and mobile soil water were used as output. Because of the limited length of the collected time series and assuming that the seasonality of the isotopic precipitation signal was similar every year, we artificially extended the input time series of precipitation by repeating the available sampled precipitation time series 20 times in a loop. This is common practice in studies where input data are limited (e.g. Hrachowitz et al., 2010, 2011; Muñoz-Villers and McDonnell, 2012; Timbe et al., 2014). 
Two-parameter models such as the gamma model (GM) or the exponential piston flow model (EPM) are commonly used for MTT estimations (Hrachowitz et al., 2010; McGuire and McDonnell, 2006). These models were identified by Timbe et al. (2014) as most suited to infer MTT estimations of spring, stream and mobile soil water in an Andean tropical montane forest catchment and were therefore applied in our study (Table 2). The selection of acceptable model parameters was based on the statistical comparison of $10^{4}$ random simulations (Monte Carlo approach), which assumes a uniform random distribution of the variables of each model. For each site and model, the performance was evaluated based on the best matches to a predefined objective function: the Nash-Sutcliffe efficiency (NSE) (Nash and Sutcliffe, 1970). Quantification of errors and deviations from the observed data were calculated using the root mean square error (RMSE) and the bias, respectively. MatLab R2017a was used for data handling and solving the convolution equation, while $R$ was used for weighting the range of behavioural solutions (generalized likelihood uncertainty estimation, GLUE) (Beven and Binley, 1992). When using GLUE, the range of behavioural solutions is discrete. Following the methods of Timbe et al. (2014), the lower limit was set to $5 \%$ below the best-fitting efficiency. In order to refine the limits of behavioural solutions, the $90 \%$ of the prediction limits were calculated for every variable through weighted quantiles between 0.05 and 0.95 .

\subsection{Young water fraction}

According to Kirchner (2016a), the estimation of MTT through tracer cycles and methods like the lumped convolution approach should be limited to homogeneous catchments for which steady state conditions apply. Because we cannot be certain of the degree of homogeneity and steady state in our study area, we complemented the analysis with the more robust calculation of the young water fraction $F_{y w}$ (Kirchner, 2016a). The $F_{y w}$ in stream water is defined as the fraction of discharge with transit times of less than approximately 0.2 years and can be calculated as the ratio of the amplitude of the stable isotope signal in stream water to the amplitude in precipitation. This is based on the assumption that the amplitude ratio will be proportional to the fraction of precipitation that bypasses storage (i.e. a near-zero transit time) (Kirchner, 2016a). We used multiple regression analysis to obtain coefficients $a$ and $b$ in Eq. (2), which were then used to estimate the amplitude with Eq. (3). The $F_{y w}$ was estimated by dividing the amplitude of the isotopic signature in stream water by that in precipitation.

$$
\begin{aligned}
& C(t)=a_{X} \cos (2 \pi f t)+b_{X} \sin (2 \pi f t)+k_{X} \\
& A_{X}=\sqrt{a_{X}^{2}+b_{X}^{2}}
\end{aligned}
$$

In Eqs. (2) and (3), $C(t)$ is the isotopic composition (\%o) of $X$ (either precipitation or stream water) at time $t$ (dec- imal years), the seasonal cycle is given in radians, $f$ is the frequency $\left(\mathrm{yr}^{-1}\right), k_{X}$ the vertical offset to the isotope signal (\%o) and $A_{X}$ is the amplitude (\%o). As suggested by Kirchner (2016b) and demonstrated by von Freyberg et al. (2018), additional information on the hydrological behaviour of catchments can be obtained by the estimation of the $F_{y w}$ for different discharge classes. Therefore, we divided the stream water dataset in samples taken during low flow (smaller than or equal to median streamflow) and high flow and estimated $F_{y w}$ for each set of stream water samples separately.

\section{Results}

\subsection{Solute concentrations}

Solute concentrations were significantly lower in precipitation than in stream water in all catchments $(p<0.05$; Table 3). Concentrations of $\mathrm{Rb}, \mathrm{Sr}, \mathrm{Mg}$ and $\mathrm{K}$ in throughfall were 3-40 times higher than in precipitation in the natural forest, smallholder agriculture, and tea and tree plantation sub-catchments $(p<0.05)$ and had a larger range. For throughfall, only $\mathrm{Rb}$ showed a significantly lower concentration in SHA (median: $\left.2.6 \mu \mathrm{g} \mathrm{L}^{-1}\right)$ than in NF $\left(23.8 \mu \mathrm{g} \mathrm{L}^{-1}\right)$ and TTP $\left(15.6 \mu \mathrm{g} \mathrm{L}^{-1}\right)$. All other solute concentrations in throughfall did not differ significantly between catchments. Solute concentrations in springs SP.b in NF and the main catchment (OUT), wetland WL in SHA and springs SP.a in TTP were generally not significantly different from stream water samples of the respective catchments $(p>0.05)$. Solute concentrations in spring samples SP.a in NF were up to 4 times higher than in stream water. Samples from shallow well WE.b in SHA had up to 8 times higher solute concentrations than stream water. Concentrations of $\mathrm{Li}$ and $\mathrm{Na}$ were higher in groundwater-related endmembers than in precipitation and throughfall, with median concentrations ranging from 1.3 to $5.0 \mu \mathrm{g} \mathrm{L}^{-1}$ for $\mathrm{Li}$ and 1.1 to $3.5 \mathrm{mg} \mathrm{L}^{-1}$ for $\mathrm{Na}$ in springs, wetland and shallow wells (SP.a, SP.b, WE.a, WE.b and WL) versus 0.19 to $0.62 \mu \mathrm{g} \mathrm{L}^{-1}$ for $\mathrm{Li}$ and 0.20 to $0.71 \mathrm{mg} \mathrm{L}^{-1}$ for $\mathrm{Na}$ in precipitation and throughfall. $\mathrm{Rb}$ and $\mathrm{K}$ were correspondingly high in groundwaterrelated endmembers (median concentrations ranging from 3.2 to $34.7 \mu \mathrm{g} \mathrm{L}^{-1}$ for $\mathrm{Rb}$ and 0.6 to $10.0 \mathrm{mg} \mathrm{L}^{-1}$ for $\mathrm{K}$ ), but concentrations in throughfall in NF and TTP were similar with median concentration of 23.8 and $15.6 \mu \mathrm{g} \mathrm{L}^{-1}$ for $\mathrm{Rb}$, and 6.1 and $4.2 \mathrm{mg} \mathrm{L}^{-1}$ for $\mathrm{K}$ in NF and TTP, respectively. These elements ( $\mathrm{Li}, \mathrm{Na}, \mathrm{Rb}$ and $\mathrm{K})$, which are indicative of mineral origin, contributed on average $90.1 \pm 10.7 \%$ of the total dissolved solute concentration in all samples. In $\mathrm{NF}$, solute concentrations in stream water were fairly constant throughout the year, with a small increase at the start of the rainy season in March 2016 (Supplement Fig. S1). A similar increase was observed for most solutes in stream water in SHA and OUT, but not in TTP (Figs. S2-S4). Concentra- 
Table 2. The lumped parameter models used for the estimation of mean transit times in the South-West Mau, Kenya.

\begin{tabular}{lll}
\hline Model & Transit time distribution $g(\tau)$ & $\begin{array}{l}\text { Parameter range for Monte } \\
\text { Carlo simulations }\end{array}$ \\
\hline Gamma model (GM) & $\frac{\tau^{\alpha-1}}{\beta^{\alpha} \Gamma(\alpha)} \exp \left(-\frac{\tau}{\beta}\right)$ & $\begin{array}{l}\alpha[0.0001-10] \\
\tau[1-400] \\
\beta=\alpha / \tau\end{array}$ \\
\hline Exponential piston flow model (EPM) & $\frac{\eta}{\tau} \exp \left(-\frac{\eta t}{\tau}+\eta-1\right)$ for $t \geq \tau\left(1-\eta^{-1}\right)$ & $\tau[1-400]$ \\
& 0 for $t<\tau\left(1-\eta^{-1}\right)$ & $\eta[0.1-4]$ \\
\hline$*_{\tau}$ is the the & & \\
\hline
\end{tabular}

${ }^{*} \tau$ is the tracer's mean transit time. $\alpha$ and $\beta$ are the shape parameters; $\eta$ is the ratio of the total volume to the volume of water with exponential distribution of transit times. Units for parameters and their respective ranges are dimensionless except for $\tau$, which has units of weeks.

tions of $\mathrm{K}$ in stream water did not differ between the catchments $(p=0.22)$. The solute composition of stream water was most similar for TTP and OUT, with most solutes showing no significant difference, while NF had generally lowest concentrations for all solutes. Sr and $\mathrm{Ba}$ concentrations in stream water were significantly higher in SHA (median: 33.3 and $19.8 \mu \mathrm{g} \mathrm{L}^{-1}$, respectively) than in all other catchments $(p<0.05)$.

\subsection{Isotopic composition}

Isotopic values for precipitation plotted slightly above the global meteoric water line (GMWL), resulting in a local meteoric water line (LMWL) with a slope of $8.05 \pm 0.21$ and an intercept of $15.31 \pm 0.61 \quad\left(p<0.001, R^{2}=0.962\right.$; Fig. 2). The slopes of the LMWL and GMWL were not significantly different $(p=0.619)$, but the intercepts were $(p<0.001)$. Samples with low volume $(<100 \mathrm{~mL})$ fell below the LMWL, which suggests evaporative enrichment. Although these samples were not used for the development of the LMWL, they were included in the mean transit time analysis. The slope of the linear regression for stream water samples was $5.00 \pm 0.54$, which was significantly smaller than the slope of the LMWL $(p<0.001)$. Precipitation samples collected at higher altitude (SHA-PC) were generally more depleted than those collected at lower altitudes (NFPC, TTP-PC and OUT-PC), with a change of $-0.099 \% \circ \delta^{18} \mathrm{O}$ per $100 \mathrm{~m}$. However, linear regression analysis revealed there was no effect of elevation on $\delta^{18} \mathrm{O}$ values of the precipitation samples $(p=0.08)$.

There was very little variation in $\delta^{18} \mathrm{O}$ values in stream water throughout the study period, as indicated by the low standard deviation $(0.26 \% \circ-0.47 \%$; Table 4$)$. Conversely, values for precipitation showed pronounced minima in November 2015, May 2016 and November 2016 in all catchments, coinciding with periods of high rainfall (Fig. 3). The isotopic composition of throughfall was similar to precipitation, with a Spearman correlation coefficient $(r)$ for $\delta^{18} \mathrm{O}$ values of $0.962,0.978$ and 0.962 for NF, SHA and TTP, respectively. The isotopic composition of mobile soil water showed more variation than stream water (standard deviation of 1.64, 1.20 and $1.35 \%$ for NF-S15, OUT-S15 and OUT-S50, respectively), but the signal was more damped than that of precipitation (Fig. 3). It was not possible to collect mobile soil water samples $(n=4-47)$ every week, because the wick samplers - the devices used to collect the samples - only collect the portion of the water moving through the soil; i.e. they start to collect water for soil conditions near to saturation.

\subsection{Endmember mixing analysis}

The trace elements $\mathrm{Li}, \mathrm{Na}, \mathrm{Mg}, \mathrm{K}, \mathrm{Rb}, \mathrm{Sr}$ and $\mathrm{Ba}$ displayed conservative behaviour in all catchments and were therefore retained for EMMA. The relative root mean square error (Table S2), based on measured and projected trace element concentrations in stream water, indicated that higherdimensional endmember mixing models were more appropriate. However, the residual analysis and "rule of one" both indicated that a two-dimensional endmember mixing model with three endmembers was sufficient for all catchments. The first two eigenvectors (dimensions) explained $92.4 \%$, $90.7 \%, 89.5 \%$ and $92.4 \%$ of the variance in stream water solute concentrations in NF, SHA, TTP and OUT, respectively.

Based on the projection of all endmembers in the stream water mixing space for each catchment, three endmembers were selected that enclosed most of the stream water samples (Fig. 4). Although most stream water samples fell within the triangle of the three selected endmembers in NF, $42 \%, 49 \%$ and $33 \%$ of the samples fell outside the triangle in SHA, TTP and OUT, respectively. Predicted stream water solute concentrations, based on median solute concentrations of the selected endmembers, matched well with observed stream water solute concentrations $\left(R^{2}>0.85\right.$ for most solutes). The poorest predictions were for Li in TTP $\left(R^{2}=0.683\right)$ and $\mathrm{Ba}$ in SHA $\left(R^{2}=0.755\right)$. The EMMA resulted in a dominant contribution of precipitation (PC) in NF (median: $46.4 \%$, $95 \%$ confidence interval: $30.5 \%-54.4 \%)$ and SHA $(57.4 \%$, $45.3 \%-78.6 \%$ ), while spring water (TTP-SP.a) dominated in TTP $(55.6 \%, 45.3 \%-70.7 \%)$ (Fig. 5). The three selected 
Table 3. Number of samples ( $n$ ), median and range (in parentheses) solute concentrations for all sampled endmembers and stream water collected between 15 October 2015 and 21 October 2016 in the South-West Mau, Kenya. Different letters after median values indicate significant differences in solute concentrations between sources.

\begin{tabular}{|c|c|c|c|c|c|c|c|c|}
\hline Source* & $n$ & $\mu \mathrm{g} \mathrm{L}^{-1}$ & $\begin{array}{r}\mathrm{Rb} \\
\mu \mathrm{g} \mathrm{L}^{-1}\end{array}$ & $\mu g \mathrm{~L}^{-1}$ & $\mu g \mathrm{~L}^{-1}$ & $\mathrm{mg} \mathrm{L}^{-1}$ & $\begin{array}{r}\mathrm{Mg} \\
\mathrm{mg} \mathrm{L}\end{array}$ & $\mathrm{mg} \mathrm{L}^{-1}$ \\
\hline \multicolumn{9}{|c|}{ Natural forest (NF) } \\
\hline RV & 55 & $\begin{array}{r}1.91 \mathrm{a} \\
(0.49-4.83)\end{array}$ & $\begin{array}{r}6.34 a \\
(1.91-16.84)\end{array}$ & $\begin{array}{r}10.15 \mathrm{a} \\
(3.17-18.70)\end{array}$ & $\begin{array}{r}5.35 \mathrm{a} \\
(1.70-11.68)\end{array}$ & $\begin{array}{r}1.78 \mathrm{ac} \\
(0.63-3.91)\end{array}$ & $\begin{array}{r}0.25 a \\
(0.07-0.55)\end{array}$ & $\begin{array}{r}1.66 \mathrm{a} \\
(0.56-3.71)\end{array}$ \\
\hline $\mathrm{PC}$ & 11 & $\begin{array}{r}0.19 b \\
(0.01-0.41)\end{array}$ & $\begin{array}{r}0.52 b \\
(0.13-1.94)\end{array}$ & $\begin{array}{r}1.20 \mathrm{~b} \\
(0.39-11.12)\end{array}$ & $\begin{array}{r}0.63 b \\
(0.21-2.99)\end{array}$ & $\begin{array}{r}0.30 \mathrm{~b} \\
(0.18-0.87)\end{array}$ & $\begin{array}{r}0.02 \mathrm{~b} \\
(0.01-0.14)\end{array}$ & $\begin{array}{r}0.24 \mathrm{~b} \\
(0.05-0.87)\end{array}$ \\
\hline SP.a & 2 & $\begin{array}{r}4.95 \mathrm{a} \\
(4.85-5.05)\end{array}$ & $\begin{array}{r}12.75 \mathrm{ac} \\
(10.16-15.34)\end{array}$ & $\begin{array}{r}13.58 \mathrm{a} \\
(12.96-14.20)\end{array}$ & $\begin{array}{r}20.45 \mathrm{a} \\
(17.82-23.07)\end{array}$ & $\begin{array}{r}3.16 \mathrm{a} \\
(2.88-3.44)\end{array}$ & $\begin{array}{r}0.33 \mathrm{a} \\
(0.28-0.38)\end{array}$ & $\begin{array}{r}2.79 \mathrm{ac} \\
(2.22-3.36)\end{array}$ \\
\hline SP.b & 3 & $\begin{array}{r}2.98 \mathrm{a} \\
(1.32-3.49)\end{array}$ & $\begin{array}{r}3.16 b \\
(2.73-3.60)\end{array}$ & $\begin{array}{r}6.80 \mathrm{ab} \\
(6.29-7.26)\end{array}$ & $\begin{array}{r}8.73 a \\
(8.32-10.82)\end{array}$ & $\begin{array}{r}1.11 b c \\
(0.86-1.28)\end{array}$ & $\begin{array}{r}0.17 \mathrm{ab} \\
(0.17-0.18)\end{array}$ & $\begin{array}{r}0.63 b \\
(0.53-0.78)\end{array}$ \\
\hline $\mathrm{TF}$ & 11 & $\begin{array}{r}0.27 b \\
(0.03-0.65)\end{array}$ & $\begin{array}{r}23.80 \mathrm{c} \\
(8.88-56.78)\end{array}$ & $\begin{array}{r}6.37 \mathrm{ab} \\
(2.94-12.10)\end{array}$ & $\begin{array}{r}3.26 \mathrm{c} \\
(1.99-8.43)\end{array}$ & $\begin{array}{r}0.33 b \\
(0.22-1.78)\end{array}$ & $\begin{array}{r}0.34 \mathrm{a} \\
(0.08-0.65)\end{array}$ & $\begin{array}{r}6.14 \mathrm{c} \\
(2.02-11.27)\end{array}$ \\
\hline \multicolumn{9}{|c|}{ Smallholder agriculture (SHA) } \\
\hline RV & 55 & $\begin{array}{r}1.63 \mathrm{a} \\
(0.37-3.79)\end{array}$ & $\begin{array}{r}5.85 \mathrm{a} \\
(2.01-16.54)\end{array}$ & $\begin{array}{r}33.33 \mathrm{a} \\
(8.68-107.27)\end{array}$ & $\begin{array}{r}19.84 \mathrm{a} \\
(4.38-48.63)\end{array}$ & $\begin{array}{r}2.13 a \\
(0.79-9.40)\end{array}$ & $\begin{array}{r}0.40 \mathrm{a} \\
(0.17-1.24)\end{array}$ & $\begin{array}{r}1.62 \mathrm{ac} \\
(0.57-4.54)\end{array}$ \\
\hline PC & 9 & $\begin{array}{r}0.24 b \\
(0.01-0.92)\end{array}$ & $\begin{array}{r}0.70 b \\
(0.38-1.18)\end{array}$ & $\begin{array}{r}2.61 \mathrm{~b} \\
(0.34-5.37)\end{array}$ & $\begin{array}{r}1.17 b \\
(0.34-8.11)\end{array}$ & $\begin{array}{r}0.37 b \\
(0.22-0.78)\end{array}$ & $\begin{array}{r}0.02 b \\
(0.01-0.10)\end{array}$ & $\begin{array}{r}0.23 b \\
(0.20-0.52)\end{array}$ \\
\hline $\mathrm{TF}$ & 9 & $\begin{array}{r}0.31 b \\
(0.01-0.53)\end{array}$ & $\begin{array}{r}2.63 a \\
(0.85-19.75)\end{array}$ & $\begin{array}{r}4.14 b c \\
(0.95-13.89)\end{array}$ & $\begin{array}{r}1.51 b c \\
(0.56-8.35)\end{array}$ & $\begin{array}{r}0.59 b c \\
(0.14-1.42)\end{array}$ & $\begin{array}{r}0.22 \mathrm{ab} \\
(0.05-0.92)\end{array}$ & $\begin{array}{r}1.01 \mathrm{ac} \\
(0.47-16.32)\end{array}$ \\
\hline WE.a & 18 & $\begin{array}{r}1.32 \mathrm{a} \\
(0.18-4.41)\end{array}$ & $\begin{array}{r}4.33 \mathrm{a} \\
(1.00-20.87)\end{array}$ & $\begin{array}{r}10.69 \mathrm{~cd} \\
(2.06-40.05)\end{array}$ & $\begin{array}{r}8.47 \mathrm{~cd} \\
(1.36-26.92)\end{array}$ & $\begin{array}{r}1.45 \mathrm{ab} \\
(0.16-4.80)\end{array}$ & $\begin{array}{r}0.18 b \\
(0.03-1.18)\end{array}$ & $\begin{array}{r}1.01 \mathrm{c} \\
(0.18-6.01)\end{array}$ \\
\hline WE.b & 2 & $\begin{array}{r}4.62 \mathrm{a} \\
(2.6-6.63)\end{array}$ & $\begin{array}{r}34.65 \mathrm{a} \\
(24.26-45.04)\end{array}$ & $\begin{array}{r}113.54 a \\
(88.93-138.15)\end{array}$ & $\begin{array}{r}155.32 \mathrm{a} \\
(123.88-186.76)\end{array}$ & $\begin{array}{r}3.29 \mathrm{ac} \\
(2.02-4.57)\end{array}$ & $\begin{array}{r}2.34 \mathrm{a} \\
(1.72-2.97)\end{array}$ & $\begin{array}{r}9.99 a \\
(7.23-12.74)\end{array}$ \\
\hline WL & 4 & $\begin{array}{r}2.49 \mathrm{a} \\
(0.6-4.08)\end{array}$ & $\begin{array}{r}7.26 \mathrm{a} \\
(3.23-21.60)\end{array}$ & $\begin{array}{r}22.30 \mathrm{ad} \\
(8.20-50.71)\end{array}$ & $\begin{array}{r}18.53 \mathrm{ad} \\
(5.13-32.32)\end{array}$ & $\begin{array}{r}3.45 \mathrm{a} \\
(1.29-4.18)\end{array}$ & $\begin{array}{r}0.42 \mathrm{a} \\
(0.19-0.71)\end{array}$ & $\begin{array}{r}2.06 \mathrm{ac} \\
(1.03-4.96)\end{array}$ \\
\hline \multicolumn{9}{|c|}{ Tea and tree plantations (TTP) } \\
\hline $\mathrm{RV}$ & 55 & $\begin{array}{r}2.32 \mathrm{a} \\
(0.75-5.45)\end{array}$ & $\begin{array}{r}7.69 a \\
(2.86-17.81)\end{array}$ & $\begin{array}{r}13.11 \mathrm{a} \\
(3.81-30.55)\end{array}$ & $\begin{array}{r}9.18 \mathrm{a} \\
(3.01-86.18)\end{array}$ & $\begin{array}{r}2.77 \mathrm{a} \\
(1.01-4.95)\end{array}$ & $\begin{array}{r}0.34 a \\
(0.10-0.60)\end{array}$ & $\begin{array}{r}1.88 \mathrm{a} \\
(0.58-3.34)\end{array}$ \\
\hline $\mathrm{PC}$ & 11 & $\begin{array}{r}0.22 \mathrm{~b} \\
(0.00-0.51)\end{array}$ & $\begin{array}{r}0.91 b \\
(0.16-1.66)\end{array}$ & $\begin{array}{r}3.44 b \\
(0.13-7.60)\end{array}$ & $\begin{array}{r}1.42 b \\
(0.12-2.82)\end{array}$ & $\begin{array}{r}0.49 b \\
(0.17-0.61)\end{array}$ & $\begin{array}{r}0.06 \mathrm{~b} \\
(0.01-0.12)\end{array}$ & $\begin{array}{r}0.37 b \\
(0.06-0.50)\end{array}$ \\
\hline SP.a & 5 & $\begin{array}{r}2.67 \mathrm{a} \\
(1.63-4.66)\end{array}$ & $\begin{array}{r}9.72 \mathrm{a} \\
(3.00-12.55)\end{array}$ & $\begin{array}{r}14.56 \mathrm{a} \\
(5.17-21.26)\end{array}$ & $\begin{array}{r}14.82 \mathrm{a} \\
(4.22-23.57)\end{array}$ & $\begin{array}{r}2.61 \mathrm{a} \\
(0.95-4.31)\end{array}$ & $\begin{array}{r}0.52 \mathrm{a} \\
(0.16-0.67)\end{array}$ & $\begin{array}{r}2.43 \mathrm{a} \\
(0.79-3.43)\end{array}$ \\
\hline $\mathrm{TF}$ & 11 & $\begin{array}{r}0.62 b \\
(0.05-3.68) \\
\end{array}$ & $\begin{array}{r}15.59 \mathrm{a} \\
(2.93-69.08) \\
\end{array}$ & $\begin{array}{r}10.06 \mathrm{a} \\
(1.4-77.26) \\
\end{array}$ & $\begin{array}{r}6.08 b \\
(0.42-19.42) \\
\end{array}$ & $\begin{array}{r}0.71 b \\
(0.07-1.26) \\
\end{array}$ & $\begin{array}{r}0.33 \mathrm{a} \\
(0.04-0.69) \\
\end{array}$ & $\begin{array}{r}4.23 a \\
(0.70-14.56) \\
\end{array}$ \\
\hline \multicolumn{9}{|c|}{ Main catchment (OUT) } \\
\hline RV & 54 & $\begin{array}{r}2.17 \mathrm{a} \\
(0.06-5.59)\end{array}$ & $\begin{array}{r}6.81 \mathrm{a} \\
(2.59-19.84)\end{array}$ & $\begin{array}{r}12.46 \mathrm{a} \\
(2.39-34.63)\end{array}$ & $\begin{array}{r}8.11 \mathrm{a} \\
(1.59-45.30)\end{array}$ & $\begin{array}{r}2.13 a \\
(0.21-5.64)\end{array}$ & $\begin{array}{r}0.30 \mathrm{a} \\
(0.08-0.79)\end{array}$ & $\begin{array}{r}1.53 \mathrm{a} \\
(0.62-3.93)\end{array}$ \\
\hline PC & 9 & $\begin{array}{r}0.28 b \\
(0.01-0.43)\end{array}$ & $\begin{array}{r}0.34 b \\
(0.09-2.10)\end{array}$ & $\begin{array}{r}1.67 b \\
(0.27-10.93)\end{array}$ & $\begin{array}{r}0.32 b \\
(0.22-2.48)\end{array}$ & $\begin{array}{r}0.20 \mathrm{~b} \\
(0.08-1.08)\end{array}$ & $\begin{array}{r}0.02 b \\
(0.01-0.29)\end{array}$ & $\begin{array}{r}0.14 \mathrm{a} \\
(0.03-0.92)\end{array}$ \\
\hline SP.b & 1 & 2.42 & 5.06 & 11.36 & 4.59 & 1.42 & 0.16 & 0.99 \\
\hline
\end{tabular}

* RV, stream water; PC, precipitation; SP.a and SP.b, springs; TF, throughfall; WE.a and WE.b, shallow wells; WL, wetland.

endmembers for OUT generally had similar contributions ranging from $30 \%$ to $40 \%$. The contribution of wetland WL in SHA increased from $2.1(-3.0-24.2) \%$ during low flow to 53.0 (23.0-91.3) \% during periods of high flow, similar to contributions of springs SP.a in NF $(16.5 \%, 11.3 \%-22.9 \%$ to $20.7 \%, 15.2 \%-34.7 \%)$ and TTP $(50.2 \%, 30.5 \%-62.5 \%$ to $69.4 \%, 43.0 \%-123.9 \%)$. Conversely, shallow well SHAWE.b in SHA showed highest contributions during the dry season (up to $54 \%$ ). The EMMA resulted in large over- and 

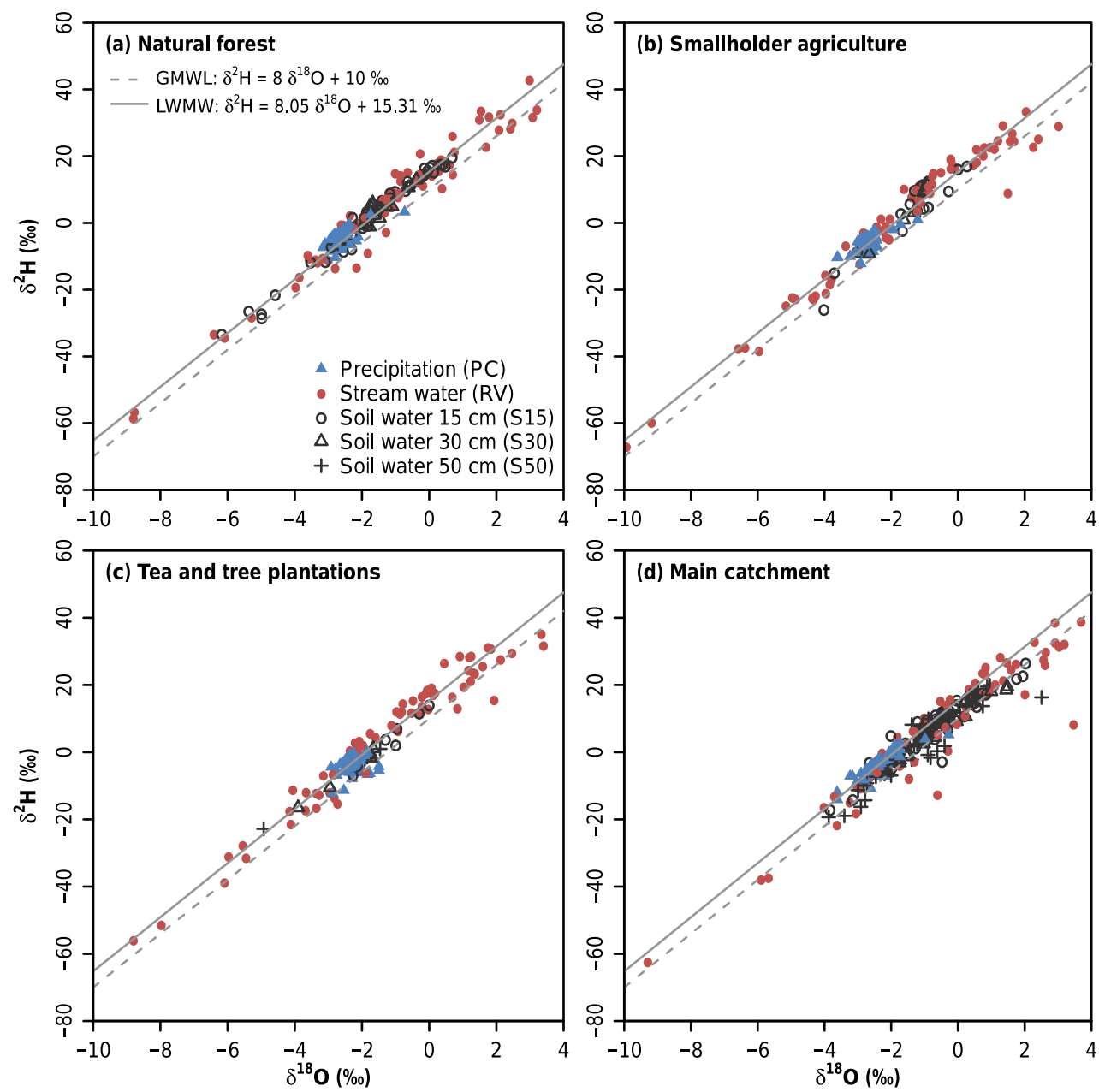

Figure 2. Relationship between $\delta^{18} \mathrm{O}$ and $\delta^{2} \mathrm{H}$ values in precipitation (PC), stream water (RV) and mobile soil water at 15,30 and $50 \mathrm{~cm}$ depth (S15, S30 and S50, respectively) for the (a) natural forest (NF), (b) smallholder agriculture (SHA), and (c) tea and tree plantations (TTP) sub-catchments, and (d) the main catchment (OUT) between 15 October 2015 and 17 March 2017 in the South-West Mau, Kenya. The global meteoric water line (GMWL) and local meteoric water line (LMWL) are indicated as dashed and solid lines, respectively.

underestimations and uncertainty in TTP (e.g. spring water SP.a contribution of up to $853 \%$ ).

\subsection{MTT estimates for stream and mobile soil water}

Only $\delta^{18} \mathrm{O}$ was used for MTT analysis, because the two measured conservative isotopes $\left(\delta^{18} \mathrm{O}\right.$ and $\left.\delta^{2} \mathrm{H}\right)$ showed a strong linear relationship (Fig. 2), meaning that similar estimations could be obtained by using just one isotope (Mosquera et al., 2016a). The isotopic signals of precipitation (weekly scheme, $n=75$ ) were considered as the input function of the lumped parameter models. All the available weekly isotope data for stream water $(n=75)$ were included in the analysis. Although some of the stream water samples could have been taken during interflow or high-flow conditions, the highly damped isotopic signature of stream water suggested that those samples still showed a major component of "old" or baseflow water. For mobile soil water, only three sites had enough data to perform model calibration and were therefore considered: NF-S15 $(n=47)$, OUT-S15 $(n=47)$ and OUTS50 $(n=46)$.

Based on the Nash-Sutcliffe efficiency, the gamma model provided a better mean transit time estimate for stream water than the exponential piston flow model (Table 5). The results of TTP-RV were discarded because of a very low performance of both models $(\mathrm{NSE}=0.05)$. The generally low fitting efficiencies were caused by the low amplitude of seasonal isotopic signatures of $\delta^{18} \mathrm{O}$ in stream water samples from all four catchments. There was a moderate positive relationship between the standard deviation of the observed values and corresponding NSE of modelled results $\left(R^{2}=0.84\right)$. NF-RV and SHA-RV had a similar transit time distribution (Fig. S5) and estimated MTT of approximately 4 years (Table 5). The shortest estimated MTT of 2.5 years was for OUT-RV. For mobile soil water, both models (GM 

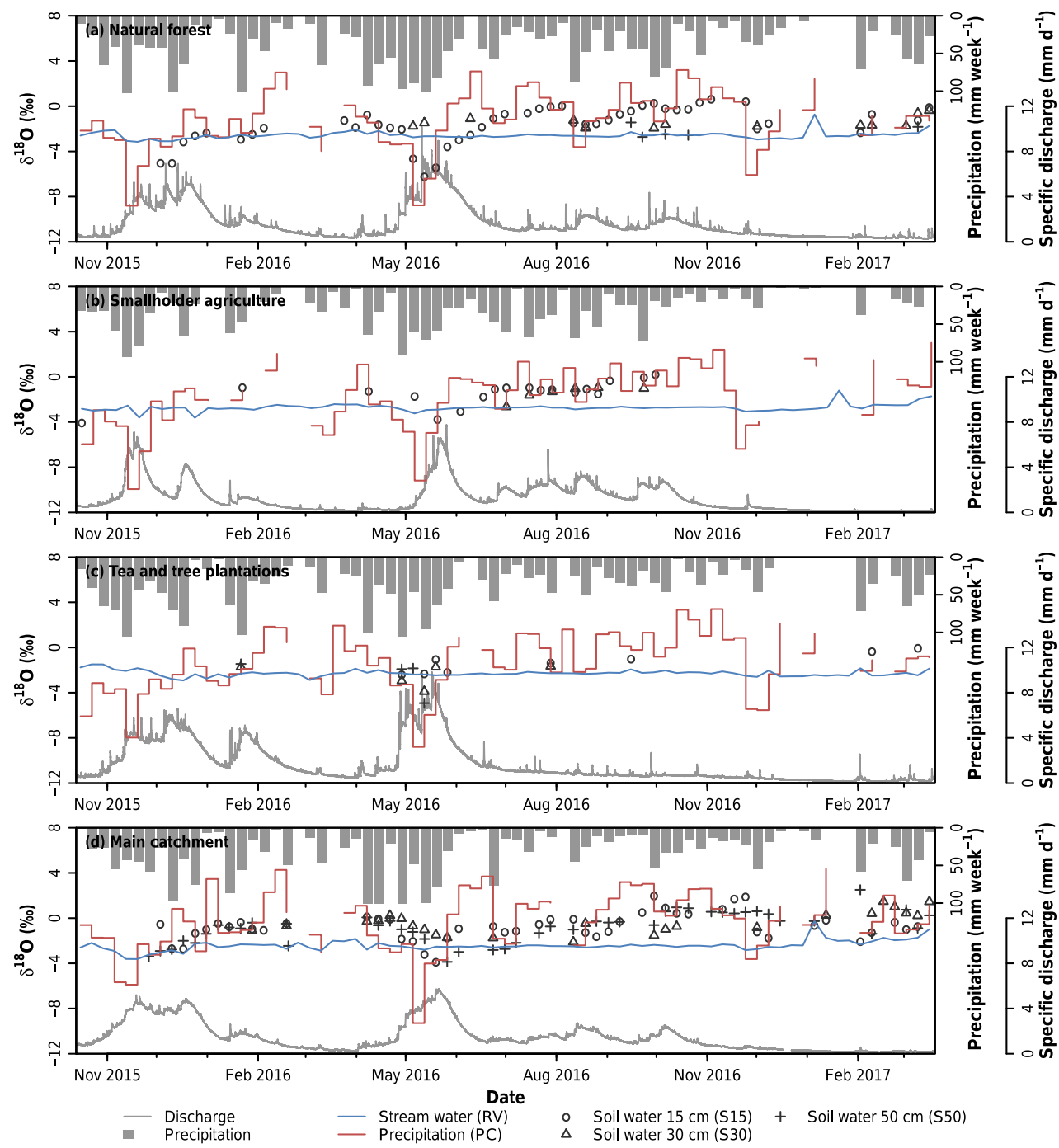

Figure 3. Time series of $\delta^{18} \mathrm{O}$ values in precipitation (PC), stream water (RV) and mobile soil water at 15,30 and $50 \mathrm{~cm}$ depth (S15, S30 and S50, respectively); specific discharge and weekly precipitation in the (a) natural forest (NF), (b) smallholder agriculture (SHA), and (c) tea and tree plantations (TTP) sub-catchments, and (d) the main catchment (OUT) between 15 October 2015 and 17 March 2017 in the South-West Mau, Kenya.

and EPM) yielded similar results in terms of fitting efficiencies (NSE), MTT estimations and uncertainty ranges (Table 6), although comparison of transit time distributions using quantile plots suggests that the models resulted in slightly different distributions (Fig. S6). NF-S15 showed the shortest estimated transit time (3.2-3.3 weeks), while estimated transit time for OUT-S15 was 4.5-7.9 weeks and for OUTS50 10.4-10.8 weeks. The selected parameter ranges for behavioural models and uncertainty in modelled $\delta^{18} \mathrm{O}$ signatures in stream and mobile soil water are presented in Figs. S7-S15.

\subsection{Young water fraction}

Due to the occurrence of two minima in the isotopic signature of rainfall, we used a frequency of 2 in the estimation of the amplitude of the seasonal cycle. We estimated the $F_{y w}$ over the whole study period at $15 \%, 13 \%$ and $15 \%$ for NF, SHA and TTP, respectively, while OUT had a $F_{y w}$ of $22 \%$. The $F_{y w}$ in SHA and TTP decreased from $18 \%$ in both sub-catchments during low flow to $5 \%$ and $12 \%$ during high flow, indicating an increased groundwater contribution to streamflow with increasing discharge in these subcatchments. The $F_{y w}$ increased slightly from $11 \%$ to $14 \%$ in NF and remained similar under low- and high-flow conditions in OUT (18\% and $19 \%$, respectively). 
Table 4. Number of samples $(n)$, coordinates, elevation, and summary statistics of $\delta^{18} \mathrm{O}$ values of samples collected at all sampling sites between 15 October 2015 and 21 October 2016 in the South-West Mau, Kenya.

\begin{tabular}{|c|c|c|c|c|c|c|c|}
\hline Source* & $n$ & Coordinates & $\begin{array}{l}\text { Elevation } \\
m\end{array}$ & $\begin{array}{l}\text { Mean } \\
\% o\end{array}$ & $\begin{array}{r}\text { Standard deviation } \\
\% \circ\end{array}$ & $\begin{array}{r}\text { Minimum } \\
\% 0\end{array}$ & $\begin{array}{r}\text { Maximum } \\
\% \circ\end{array}$ \\
\hline \multicolumn{8}{|c|}{ Natural forest (NF) } \\
\hline RV & 75 & $35^{\circ} 18^{\prime} 32.616^{\prime \prime} \mathrm{E}, 0^{\circ} 27^{\prime} 48.570^{\prime \prime} \mathrm{S}$ & 1969 & -2.58 & 0.32 & -3.15 & -0.73 \\
\hline $\mathrm{PC}$ & 68 & $35^{\circ} 18^{\prime} 32.232^{\prime \prime} \mathrm{E}, 0^{\circ} 27^{\prime} 47.862^{\prime \prime} \mathrm{S}$ & 1964 & -1.20 & 2.49 & -8.80 & 3.20 \\
\hline S15 & 47 & $35^{\circ} 18^{\prime} 35.508^{\prime \prime} \mathrm{E}, 0^{\circ} 27^{\prime} 46.938^{\prime \prime} \mathrm{S}$ & 1971 & -1.62 & 1.64 & -6.18 & 0.68 \\
\hline S30 & 13 & $35^{\circ} 18^{\prime} 35.508^{\prime \prime} \mathrm{E}, 0^{\circ} 27^{\prime} 46.938^{\prime \prime} \mathrm{S}$ & 1971 & -1.46 & 0.49 & -1.94 & -0.38 \\
\hline S50 & 6 & $35^{\circ} 18^{\prime} 35.508^{\prime \prime} \mathrm{E}, 0^{\circ} 27^{\prime} 46.938^{\prime \prime} \mathrm{S}$ & 1971 & -2.20 & 0.49 & -2.72 & -1.44 \\
\hline SP.a & 2 & $35^{\circ} 19^{\prime} 53^{\prime \prime} \mathrm{E}, 0^{\circ} 26^{\prime} 5^{\prime \prime} \mathrm{S}$ & 2081 & -2.31 & 0.02 & -2.32 & -2.29 \\
\hline SP.b & 3 & $35^{\circ} 19^{\prime} 47.292^{\prime \prime} \mathrm{E}, 0^{\circ} 26^{\prime} 21.246^{\prime \prime} \mathrm{S}$ & 2070 & -2.67 & 0.04 & -2.71 & -2.63 \\
\hline $\mathrm{TF}$ & 66 & $35^{\circ} 18^{\prime} 35.268^{\prime \prime} \mathrm{E}, 0^{\circ} 27^{\prime} 46.842^{\prime \prime} \mathrm{S}$ & 1965 & -0.83 & 2.32 & -8.37 & 3.22 \\
\hline \multicolumn{8}{|c|}{ Smallholder agriculture (SHA) } \\
\hline RV & 75 & $35^{\circ} 28^{\prime} 31.452^{\prime \prime} \mathrm{E}, 0^{\circ} 24^{\prime} 3.930^{\prime \prime} \mathrm{S}$ & 2386 & -2.72 & 0.31 & -3.62 & -1.21 \\
\hline $\mathrm{PC}$ & 65 & $35^{\circ} 28^{\prime} 27.324^{\prime \prime} \mathrm{E}, 0^{\circ} 24^{\prime} 2.322^{\prime \prime} \mathrm{S}$ & 2401 & -1.62 & 2.68 & -9.93 & 3.02 \\
\hline S15 & 18 & $35^{\circ} 28^{\prime} 31.812^{\prime \prime} \mathrm{E}, 0^{\circ} 24^{\prime} 0.504^{\prime \prime} \mathrm{S}$ & 2395 & -1.39 & 1.14 & -4.02 & 0.27 \\
\hline S30 & 6 & $35^{\circ} 28^{\prime} 31.812^{\prime \prime} \mathrm{E}, 0^{\circ} 24^{\prime} 0.504^{\prime \prime} \mathrm{S}$ & 2395 & -1.43 & 0.65 & -2.65 & -0.94 \\
\hline $\mathrm{TF}$ & 64 & $35^{\circ} 28^{\prime} 28.002^{\prime \prime} \mathrm{E}, 0^{\circ} 24^{\prime} 2.550^{\prime \prime} \mathrm{S}$ & 2393 & -1.52 & 2.63 & -9.27 & 2.86 \\
\hline WE.a & 18 & $\begin{array}{l}35^{\circ} 29^{\prime} 28.590^{\prime \prime}-35^{\circ} 32^{\prime} 3.468^{\prime \prime} \mathrm{E} \\
0^{\circ} 18^{\prime} 3.918^{\prime \prime}-0^{\circ} 23^{\prime} 47.700^{\prime \prime} \mathrm{S}\end{array}$ & $2492-2612$ & -2.64 & 0.17 & -2.89 & -2.29 \\
\hline WE.b & 2 & $35^{\circ} 32^{\prime} 29.316^{\prime \prime} \mathrm{E}, 0^{\circ} 18^{\prime} 3.450^{\prime \prime} \mathrm{S}$ & 2655 & -2.52 & 0.16 & -2.64 & -2.40 \\
\hline WL & 4 & $35^{\circ} 32^{\prime} 22.554^{\prime \prime} \mathrm{E}, 0^{\circ} 17^{\prime} 30.186^{\prime \prime} \mathrm{S}$ & 2614 & -3.06 & 0.27 & -3.40 & -2.77 \\
\hline \multicolumn{8}{|c|}{ Tea and tree plantations (TTP) } \\
\hline RV & 75 & $35^{\circ} 13^{\prime} 16.086^{\prime \prime} \mathrm{E}, 0^{\circ} 28^{\prime} 35.826^{\prime \prime} \mathrm{S}$ & 1788 & -2.29 & 0.26 & -2.92 & -1.49 \\
\hline $\mathrm{PC}$ & 68 & $35^{\circ} 18^{\prime} 1.266^{\prime \prime} \mathrm{E}, 0^{\circ} 26^{\prime} 9.348^{\prime \prime} \mathrm{S}$ & 2106 & -1.29 & 2.54 & -8.80 & 3.40 \\
\hline S15 & 8 & $35^{\circ} 18^{\prime} 1.206^{\prime \prime} \mathrm{E}, 0^{\circ} 26^{\prime} 9.144^{\prime \prime} \mathrm{S}$ & 2106 & -1.29 & 0.90 & -2.34 & 0.00 \\
\hline S30 & 5 & $35^{\circ} 18^{\prime} 1.206^{\prime \prime} \mathrm{E}, 0^{\circ} 26^{\prime} 9.144^{\prime \prime} \mathrm{S}$ & 2106 & -2.40 & 1.00 & -3.90 & -1.67 \\
\hline S50 & 4 & $35^{\circ} 18^{\prime} 1.206^{\prime \prime} \mathrm{E}, 0^{\circ} 26^{\prime} 9.144^{\prime \prime} \mathrm{S}$ & 2106 & -2.54 & 1.61 & -4.93 & -1.46 \\
\hline SP.a & 5 & $\begin{array}{l}35^{\circ} 14^{\prime} 17.592^{\prime \prime}-35^{\circ} 18^{\prime} 36.252^{\prime \prime} \mathrm{E} \\
0^{\circ} 26^{\prime} 34.044^{\prime \prime}-0^{\circ} 28^{\prime} 1.698^{\prime \prime} \mathrm{S}\end{array}$ & $1862-2079$ & -2.51 & 0.15 & -2.63 & -2.26 \\
\hline $\mathrm{TF}$ & 65 & $35^{\circ} 18^{\prime} 1.110^{\prime \prime} \mathrm{E}, 0^{\circ} 26^{\prime} 9.288^{\prime \prime} \mathrm{S}$ & 2106 & -1.29 & 2.49 & -8.50 & 3.23 \\
\hline \multicolumn{8}{|c|}{ Main catchment (OUT) } \\
\hline RV & 75 & $35^{\circ} 10^{\prime} 53.046^{\prime \prime} \mathrm{E}, 0^{\circ} 28^{\prime} 59.232^{\prime \prime} \mathrm{S}$ & 1717 & -2.42 & 0.47 & -3.62 & -0.28 \\
\hline $\mathrm{PC}$ & 69 & $35^{\circ} 10^{\prime} 53.904^{\prime \prime} \mathrm{E}, 0^{\circ} 28^{\prime} 58.824^{\prime \prime} \mathrm{S}$ & 1718 & -0.34 & 2.53 & -9.29 & 4.37 \\
\hline S15 & 47 & $35^{\circ} 10^{\prime} 53.712^{\prime \prime} \mathrm{E}, 0^{\circ} 29^{\prime} 0.720^{\prime \prime} \mathrm{S}$ & 1721 & -0.68 & 1.20 & -3.83 & 2.03 \\
\hline S30 & 24 & $35^{\circ} 10^{\prime} 53.712^{\prime \prime} \mathrm{E}, 0^{\circ} 29^{\prime} 0.720^{\prime \prime} \mathrm{S}$ & 1721 & -0.43 & 0.99 & -2.12 & 1.47 \\
\hline S50 & 46 & $35^{\circ} 10^{\prime} 53.712^{\prime \prime} \mathrm{E}, 0^{\circ} 29^{\prime} 0.720^{\prime \prime} \mathrm{S}$ & 1721 & -0.84 & 1.35 & -3.87 & 2.50 \\
\hline SP.b & 1 & $35^{\circ} 21^{\prime} 50.682^{\prime \prime} \mathrm{E}, 0^{\circ} 29^{\prime} 5.208^{\prime \prime} \mathrm{S}$ & 2159 & -2.61 & NA & -2.61 & -2.61 \\
\hline
\end{tabular}

* RV, stream water; PC, precipitation; SP.a and SP.b, springs; TF, throughfall; WE.a and WE.b, shallow wells; WL, wetland; S15, S30 and S50 indicate mobile soil water at 15,30 and $50 \mathrm{~cm}$ depth, respectively. NA, not available.

\section{Discussion}

\subsection{Hydrochemistry}

Low solute concentrations in precipitation (PC) compared to other endmembers are commonly observed in the tropics (Chaves et al., 2008; Correa et al., 2017; Crespo et al., 2012). Similar to observations in the Amazon (Chaves et al., 2008), concentrations of $\mathrm{K}$ and $\mathrm{Mg}$ were higher in throughfall (TF) than in precipitation, while $\mathrm{Na}$ concentrations were similar.
Furthermore, solute concentrations in throughfall were more variable in space and time than in precipitation. This has also been observed in Canada (Ali et al., 2010) and the Brazilian Amazon (Chaves et al., 2008; Germer et al., 2007) and can be attributed to seasonal variations in plant growth and dry and wet atmospheric deposition of $\mathrm{K}$ and $\mathrm{Mg}$ originating from biomass burning in our study area. Shallow well SHA-WE.b had trace element concentrations that were much higher than those of the other nine sampled shallow wells SHA-WE.a, 
Table 5. Main statistical parameters of observed and modelled $\delta^{18} \mathrm{O}$ for stream water in the three sub-catchments and the main catchments for the gamma model (GM) and exponential piston flow model (EPM). Uncertainty bounds of the modelled parameters $(\tau$ and $\alpha$ or $\eta)$, in parentheses, were calculated through generalized likelihood uncertainty estimation (GLUE).

\begin{tabular}{|c|c|c|c|c|c|c|c|c|c|c|c|c|c|}
\hline \multirow[t]{3}{*}{ Site $^{\mathrm{a}}$} & \multirow{3}{*}{$\begin{array}{l}\text { Area } \\
\mathrm{km}^{2}\end{array}$} & \multirow{3}{*}{$\begin{array}{r}\text { Elevation } \\
m\end{array}$} & \multicolumn{2}{|c|}{ Observed $\delta^{18} \mathrm{O}$} & \multirow{3}{*}{$\begin{array}{c}F_{y w}^{\mathrm{c}} \\
\%\end{array}$} & \multirow[t]{3}{*}{ Model $^{\mathrm{d}}$} & \multicolumn{7}{|c|}{ Modelled $\delta^{18} \mathrm{O}$} \\
\hline & & & Mean & $\mathrm{SD}^{\mathrm{b}}$ & & & Mean & $\mathrm{SD}^{\mathrm{b}}$ & $\mathrm{NSE}^{\mathrm{e}}$ & RMSE $^{f}$ & Bias & $\mathrm{MTT}^{\mathrm{g}}$ & $\alpha / \eta^{\mathrm{h}}$ \\
\hline & & & $\%$ & $\%$ & & & $\%$ & $\% o$ & - & $\%$ & $\%$ & $\mathrm{yr}$ & - \\
\hline \multirow[t]{2}{*}{$\mathrm{NF}$} & 35.9 & 1969 & -2.58 & 0.32 & 15 & GM & -2.56 & 0.13 & 0.15 & 0.30 & 0.021 & $4.0(3.3-4.6)$ & $0.65(0.63-0.71)$ \\
\hline & & & & & & EPM & -2.58 & 0.10 & 0.09 & 0.31 & 0.000 & n.a. & n.a. \\
\hline \multirow[t]{2}{*}{ SHA } & 27.2 & 2386 & -2.72 & 0.31 & 13 & GM & -2.69 & 0.16 & 0.22 & 0.27 & 0.029 & $3.8(3.1-4.5)$ & $0.61(0.57-0.66)$ \\
\hline & & & & & & EPM & -2.72 & 0.11 & 0.12 & 0.29 & 0.000 & n.a. & n.a. \\
\hline \multirow[t]{2}{*}{ TTP } & 33.3 & 1788 & -2.29 & 0.26 & 15 & GM & -2.29 & 0.06 & 0.05 & 0.25 & 0.000 & n.a. & n.a. \\
\hline & & & & & & EPM & -2.29 & 0.07 & 0.07 & 0.25 & 0.000 & n.a. & n.a. \\
\hline \multirow[t]{2}{*}{ OUT } & 1021.3 & 1717 & -2.42 & 0.47 & 22 & GM & -2.36 & 0.26 & 0.33 & 0.38 & 0.061 & $2.5(1.8-3.4)$ & $0.48(0.43-0.54)$ \\
\hline & & & & & & EPM & -2.42 & 0.20 & 0.14 & 0.43 & 0.001 & n.a. & n.a. \\
\hline
\end{tabular}

${ }^{\text {a }}$ NF, natural forest; SHA, smallholder agriculture; TTP, tea and tree plantations; OUT, main catchment. ${ }^{\text {b }}$ Standard deviation. ${ }^{c}$ Young water fraction (Kirchner, 2016a). ${ }^{\mathrm{d}}$ GM, gamma model; EPM, exponential piston flow model. ${ }^{\mathrm{e}}$ Nash-Sutcliffe efficiency of objective function. ${ }^{\mathrm{f}}$ Root mean square error. ${ }^{\mathrm{g}}$ Estimated mean transit time (in years). ${ }^{\mathrm{h}}$ Model parameters for GM ( $\alpha$ ) and $\operatorname{EPM}(\eta)$. n.a. indicates modelled parameters and corresponding uncertainty are not presented for models with a low NSE.

Table 6. Main statistical parameters of observed and modelled $\delta^{18} \mathrm{O}$ for mobile soil water at $15 \mathrm{~cm}$ depth in the natural forest sub-catchment and at 15 and $50 \mathrm{~cm}$ depth in the main catchment for the gamma model (GM) and exponential piston flow model (EPM). Uncertainty bounds of the modelled parameters ( $\tau$ and $\alpha$ or $\eta$ ), in parentheses, were calculated through generalized likelihood uncertainty estimation (GLUE).

\begin{tabular}{|c|c|c|c|c|c|c|c|c|c|c|c|c|}
\hline \multirow[t]{3}{*}{ Site $^{\mathrm{a}}$} & \multirow{3}{*}{$\begin{array}{l}n^{\mathrm{b}} \\
-\end{array}$} & \multirow{3}{*}{$\begin{array}{l}\text { Elevation } \\
\\
m\end{array}$} & \multicolumn{2}{|c|}{ Observed $\delta^{18} \mathrm{O}$} & \multirow[t]{3}{*}{ Model $^{\mathrm{d}}$} & \multicolumn{7}{|c|}{ Modelled $\delta^{18} \mathrm{O}$} \\
\hline & & & Mean & $\mathrm{SD}^{\mathrm{c}}$ & & Mean & $\mathrm{SD}^{\mathrm{c}}$ & $\mathrm{NSE}^{\mathrm{e}}$ & $\operatorname{RMSE}^{\mathrm{f}}$ & Bias & MTT $^{\mathrm{g}}$ & $\alpha / \eta^{\mathrm{h}}$ \\
\hline & & & $\%$ & $\%$ & & $\%$ & $\%$ & - & $\%$ & $\%$ & weeks & - \\
\hline \multirow[t]{2}{*}{ NF-S15 } & 47 & 1971 & -1.62 & 1.64 & GM & -1.74 & 1.48 & 0.79 & 0.75 & -0.12 & $3.2(2.8-4.1)$ & $1.5(0.9-2.2)$ \\
\hline & & & & & EPM & -1.67 & 1.38 & 0.78 & 0.77 & -0.05 & $3.3(2.6-4.4)$ & $1.0(0.9-1.1)$ \\
\hline \multirow[t]{2}{*}{ OUT-S15 } & 47 & 1721 & -0.68 & 1.20 & GM & -0.71 & 0.99 & 0.50 & 0.84 & -0.03 & $7.9(6.1-11.3)$ & $0.9(0.6-1.2)$ \\
\hline & & & & & EPM & -0.58 & 0.94 & 0.52 & 0.82 & 0.11 & $4.5(3.2-6.7)$ & $0.8(0.7-1.1)$ \\
\hline \multirow[t]{2}{*}{ OUT-S50 } & 46 & 1721 & -0.84 & 1.35 & GM & -0.92 & 0.93 & 0.47 & 0.97 & -0.08 & $10.4(8.8-12.6)$ & $1.4(1.1-2.0)$ \\
\hline & & & & & EPM & -0.90 & 0.85 & 0.46 & 0.99 & -0.06 & $10.8(8.0-13.9)$ & $1.0(0.9-1.3)$ \\
\hline
\end{tabular}

${ }^{a}$ NF, natural forest; OUT, main catchment; S15, mobile soil water at $15 \mathrm{~cm}$ depth; S50, mobile soil water at $50 \mathrm{~cm}$ depth. ${ }^{\mathrm{b}}$ Number of samples. ${ }^{\mathrm{c}}$ Standard deviation. ${ }^{\mathrm{d}} \mathrm{GM}$, gamma

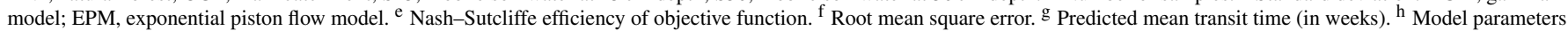
for $\mathrm{GM}(\alpha)$ and $\operatorname{EPM}(\eta)$.

but similar in magnitude to solute concentrations in a spring in the Andean Páramo (Correa et al., 2017) and deep groundwater in Tanzania (Koutsouris and Lyon, 2018). Since the trace elements with high concentrations in SHA-WE.b correspond with elements related to geology (e.g. $\mathrm{Li}, \mathrm{K}, \mathrm{Na}$ and $\mathrm{Rb}$ ), it is likely that this source is groundwater related. Wetland SHA-WL, located near shallow well SHA-WE.b, did not show these high concentrations, which could indicate that the shallow well received water from a different source than the wetland and other shallow wells. Conversely, similarity in solute concentrations in springs NF-SP.b and OUT-SP.b and shallow wells SHA-WE.a indicate that these endmembers represent the same water source, despite their different geographical location. The same was observed for wetland SHA-WL and springs NF-SP.a and TTP-SP.a.

The higher intercept of the local meteoric water line than of the global meteoric water line indicates deuterium-excess ( $d$-excess) as a consequence of more arid vapour sources (McGuire and McDonnell, 2007) or re-evaporated rainfall
(Goldsmith et al., 2012). The $d$-excess value (5.31\%o) corresponds to values observed in other tropical montane environments (e.g. Goldsmith et al., 2012; Mosquera et al., 2016a; Muñoz-Villers et al., 2016; Otte et al., 2017; Windhorst et al., 2013). The value for the slope of the linear relationship between stream water isotopic values $(5.00 \pm 0.54)$ was similar to the slope of $\sim 5$ found by Craig (1961) for East African rivers and lakes and suggests evaporative enrichment of stream water. The observed change in $\delta^{18} \mathrm{O}$ with altitude $\left(-0.099 \%\right.$ o $\delta^{18} \mathrm{O}$ per $\left.100 \mathrm{~m}\right)$ is smaller than the $-0.22 \%$ o $\delta^{18} \mathrm{O}$ per $100 \mathrm{~m}$ found in an Andean tropical montane forest (Windhorst et al., 2013), $-0.31 \% \circ \delta^{18} \mathrm{O}$ per $100 \mathrm{~m}$ in an Ecuadorian Páramo ecosystem (Mosquera et al., 2016a), but similar to values of -0.10 and $-0.11 \% \delta^{18} \mathrm{O}$ per $100 \mathrm{~m}$ observed on Mt Kilimanjaro in Tanzania (Mckenzie et al., 2010; Otte et al., 2017). The occurrence of the lowest precipitation $\delta^{18} \mathrm{O}$ values during the rainy seasons also agrees with seasonal observations by Otte et al. (2017) on Mt Kilimanjaro and is most likely related to the different isotopic composi- 

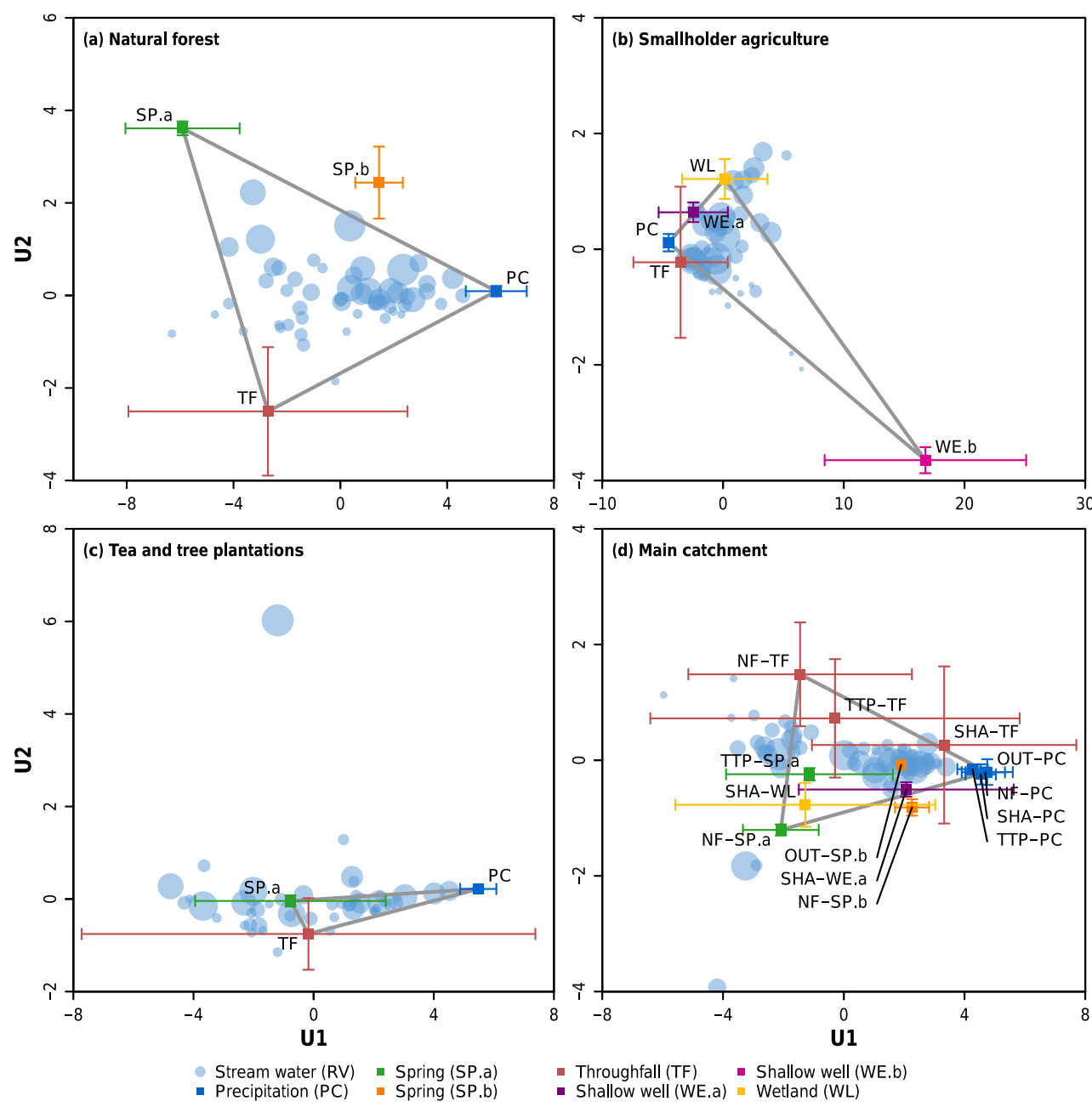

Figure 4. Projection of endmembers in the two-dimensional (U1 and U2) mixing space of stream water samples of the (a) natural forest (NF), (b) smallholder agriculture (SHA), and (c) tea and tree plantation (TTP) sub-catchments and (d) the main catchment (OUT) between 15 October 2015 and 21 October 2016 in the South-West Mau, Kenya. The size of the symbol for stream water represents the relative discharge at the time of sampling (larger symbol means higher discharge).

tion of precipitation from storms caused by the movement of the Intertropical Convergence Zone (ITCZ) over the study area during the rainy seasons (Otte et al., 2017). Furthermore, most storm trajectories originate from a south-easterly direction during the long and short rainy season, while coming from an easterly direction during the dry season, suggesting a different origin and thus isotopic composition of precipitation (Soderberg et al., 2013). Stream water isotope signals that were equally damped compared to precipitation $\left(-8.0 \%\right.$ to $-6.2 \%$ o versus $-15.2 \%$ to $-0.4 \%$ for $\delta^{18} \mathrm{O}$ in stream water and precipitation, respectively) were observed in a Mexican tropical montane forest catchment with similar deep volcanic soil (Muñoz-Villers and McDonnell, 2012).

\subsection{Dominant water sources}

The endmember mixing analysis showed that precipitation (PC) was an important endmember in all catchments, as depicted in our conceptual model of the rainfall-run-off generation processes in the three sub-catchments with different land use (Fig. 6). The high contribution of precipitation (median: $46.4 \%$, $95 \%$ confidence interval: $30.5 \%-54.4 \%$ ) to streamflow in the natural forest sub-catchment is unexpected, as a major contribution of surface run-off is not likely due to high infiltration rates and high hydraulic conductivity of forest soils (Owuor et al., 2018). Furthermore, it contradicts the low young water fraction $\left(F_{y w}\right)$ estimated for this sub-catchment. Although surface run-off can occur in tropical forests (e.g. Chaves et al., 2008; Johnson et al., 2006; de Moraes et al., 2006), we suggest that the observed signa- 

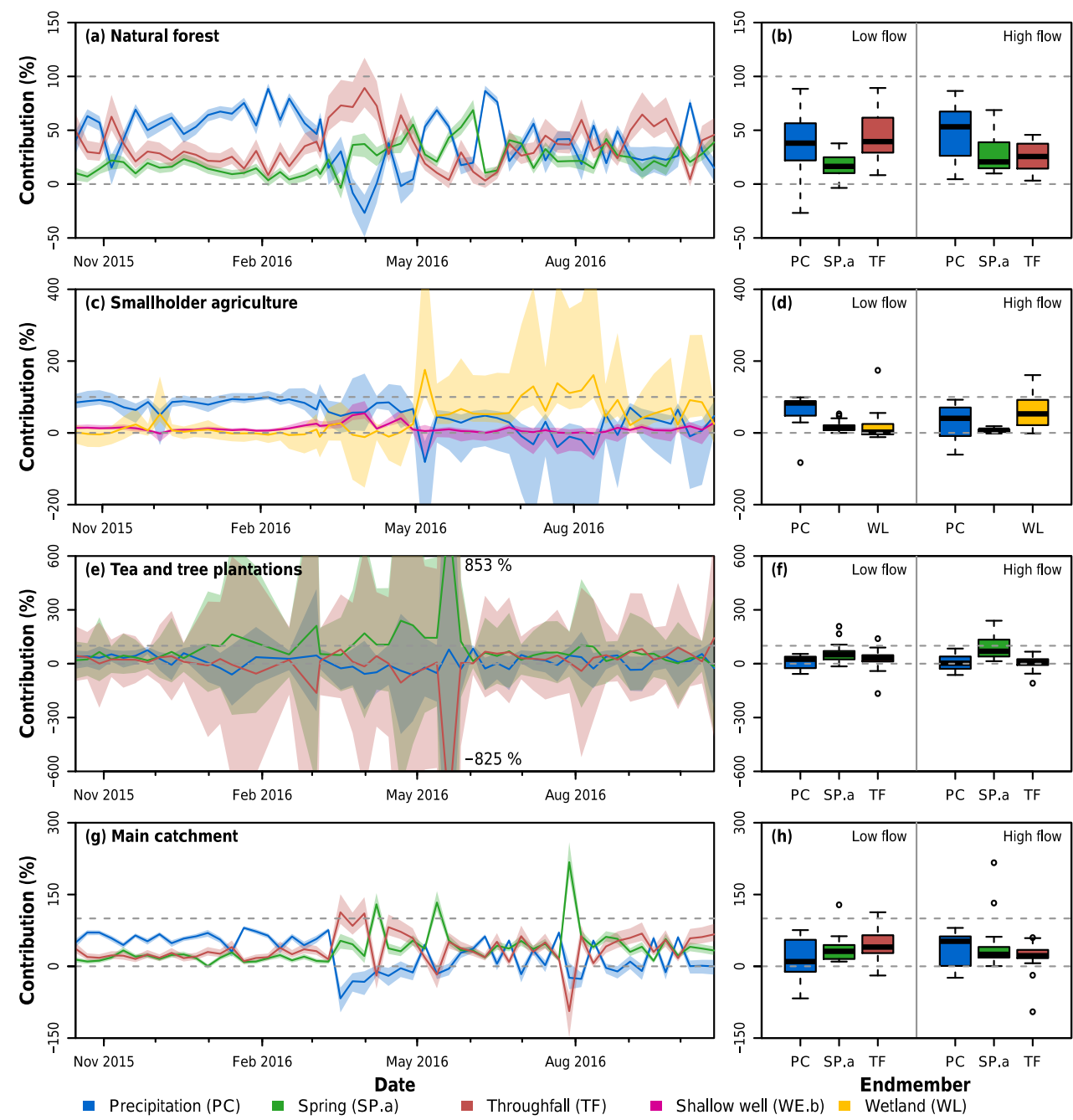

Figure 5. Contribution of selected endmembers to streamflow for the (a-b) natural forest (NF), (c-d) smallholder agriculture (SHA), and (e-f) tea and tea plantation (TTP) sub-catchments and (g-h) the main catchment (OUT) between 15 October 2015 and 21 October 2016 in the South-West Mau, Kenya. The grey dashed lines indicate the realistic range of endmember contributions. Shaded areas represent the 5th to 95th percentile of 10000 Monte Carlo simulations of the EMMA, while the line represents the median endmember contribution. The thick line in the box plots represents the median endmember contribution, separated by flow condition. The box shows the interquartile range and the whiskers the minimum and maximum values within 1.5 times the interquartile range. Outliers are indicated with open circles.

tures were caused by shallow subsurface flow during rainfall events, which agrees with findings in NF by Jacobs et al. (2018) and is commonly observed in tropical montane forested catchments (e.g. Boy et al., 2008; Muñoz-Villers and McDonnell, 2012; Saunders et al., 2006). Additionally, shallow flow from the riparian zone could occur during rainfall events, when the riparian zone is near saturation (von Freyberg et al., 2014; Mosquera et al., 2015).

Results from the EMMA support our hypothesis that surface run-off occurs in the smallholder agriculture subcatchment, which agrees with observations from, for example, Mexico (Muñoz-Villers and McDonnell, 2013) and the Amazon (Neill et al., 2011). However, it does not agree with the importance of groundwater implied by the long es- timated MTTs and small $F_{y w}$. The contribution of precipitation $(57.4 \%, 45.3 \%-78.6 \%)$ in SHA is probably overestimated due to the inclusion of shallow well SHA-WE.b as an endmember. This endmember was required to explain stream water chemistry during the dry season, but would ideally not have been used due to its small sample size. However, Correa et al. (2017) found that inclusion of a spring with similarly high solute concentrations was required in their endmember model. Similar to SHA-WE.b, this spring contributed more to streamflow during the dry season (Correa et al., 2017). In contrast to SHA, the relatively low contribution of precipitation to streamflow in the tea and tree plantation sub-catchment suggests a minor input of surface run-off to streamflow during both wet and dry conditions 
(a) Natural forest

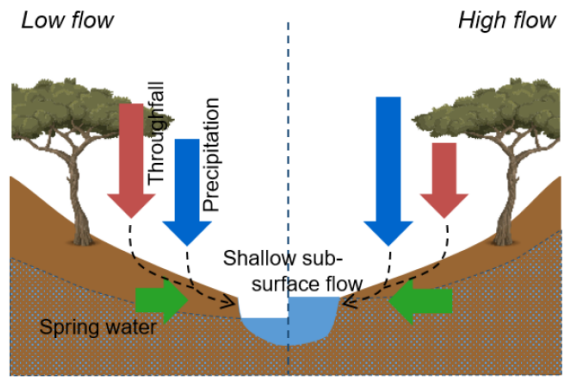

(b) Smallholder agriculture

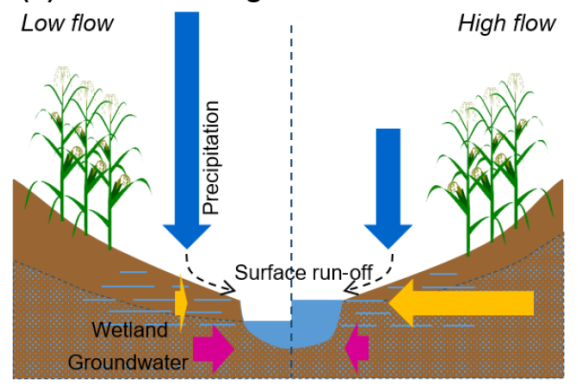

(c) Tea and tree plantations

Low flow

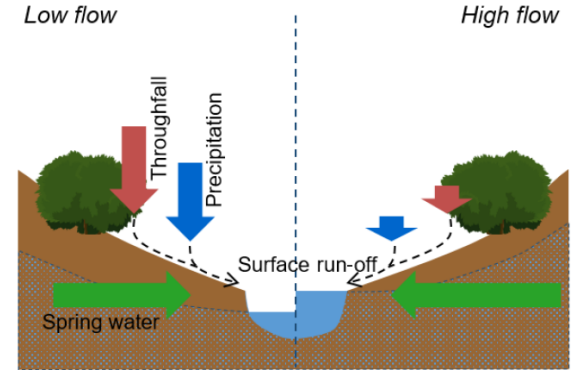

Figure 6. Conceptual model of dominant water sources and flow paths in different land use types during low ( $\leq$ median discharge) and high flows (> median discharge) in a tropical montane area: (a) natural forest (NF), (b) smallholder agriculture (SHA), and (c) commercial tea and tree plantations (TTP), based on results of endmember mixing and mean transit time analysis in the South-West Mau, Kenya. Arrow length represents the median contribution $(\%)$ of each endmember. Black dashed arrows show the most likely pathway for precipitation and throughfall to reach the stream.

(Fig. 6). This seemingly contradicts previous findings in the same sub-catchment, where rainfall events led to significant dilution of nitrate concentrations in stream water due to surface run-off (Jacobs et al., 2018). The role of precipitation as stream water source in TTP might, however, have been underestimated due to the poor performance of the endmember model and high uncertainty in results.

Similar to findings by Muñoz-Villers and McDonnell (2012) in Mexico and Chaves et al. (2008) in the Brazilian Amazon, the contribution of precipitation and throughfall decreased in all sub-catchments during high flows (Fig. 6, right hillslopes in each graph). This suggests increased inputs from groundwater through wetlands (SHA-WL) or springs (TTP-SP.a and NF-SP.a) during the rainy season.

\subsection{Mean transit times and young water fractions}

The low fitting efficiencies, high uncertainty and the long estimated MTT (i.e. in the order of years) did not allow us to accept or to reject our hypothesis that agricultural catchments have a shorter MTT than forested catchments due to increased importance of faster flow paths such as surface runoff. However, the long estimated MTTs and the low fraction of young water $\left(F_{y w}\right)$ suggest that the majority of the stream water in all catchments originates from "old" water or groundwater. This could be explained by the deep and well-drained soil in our study area (Cooper, 1979; Edwards and Blackie, 1981), compared to the shallower soils and steep slopes in, for example, Andean tropical montane forest catchments with shorter mean transit times (e.g. Crespo et al., 2012; Timbe et al., 2014). Such deep soils promote slow flow paths through deeper soil layers and thus result in longer transit times (Asano and Uchida, 2012). This finding agrees with the selection of groundwater-related endmembers springs TTP-SP.a and NF-SP.a and wetland SHA-WL in the EMMA (Fig. 6). Furthermore, the $F_{y w}$ during low and high flow follows the same trend as the estimated precipitation contribution in the three sub-catchments.

The longer MTT for mobile soil water for OUT-S15, located in a pasture, than for NF-S15 contradicts findings in an Andean tropical montane catchment: Timbe et al. (2014) compared pasture and forest soil water MTTs and found longer MTTs for forested sites. In our case, the difference could be caused by differences in hydraulic conductivity, since soil hydraulic properties can influence MTT (Geris et al., 2015; Mueller et al., 2013; Muñoz-Villers et al., 2016). Pasture soils in our study area had a generally lower hydraulic conductivity $\left(2-53 \mathrm{~cm} \mathrm{~h}^{-1}\right)$ than natural forest soils $\left(10-207 \mathrm{~cm} \mathrm{~h}^{-1}\right)$ due to soil compaction by livestock trampling (Owuor et al., 2018). The estimated MTTs fell within the range observed for soil water from 30 to $60 \mathrm{~cm}$ depth (2062 days) in a tropical montane catchment in Mexico (MuñozVillers and McDonnell, 2012).

\subsection{Methodological limitations and implications for further research}

There was a large uncertainty in endmember contributions, which is related to the large number of samples falling outside the triangle bounded by the three selected endmembers in SHA, TTP and OUT (Figs. 4-5). Although this could be attributed to the variability in endmember composition, uncertainty in laboratory analysis or non-conservative solute behaviour (Barthold et al., 2010), it is very likely that one or more important endmembers are missing. Furthermore, inclusion of additional endmembers to increase the dimensionality of the endmember model may be required, as was necessary in an Andean Páramo ecosystem (Correa et al., 2017) and a tropical forested catchment in Panama (Barthold et al., 2017). Since our results suggest that our catchments are largely groundwater dominated, deep groundwater is most likely an important missing endmember in our analysis, as observed in many studies (e.g. Barthold et al., 2011; Chaves 
et al., 2008; Crespo et al., 2012; Katsuyama et al., 2009). However, access to groundwater in the study area is complicated by the absence of wells or boreholes in NF and TTP. Furthermore, the existing wells in SHA are often not properly sealed, which means that deep groundwater can mix with water from shallower soil layers and precipitation, obscuring the groundwater signal. In addition to groundwater, inclusion of soil water might improve the mixing models, as other studies in tropical montane regions showed the importance of soil water as source of streamflow (Chaves et al., 2008; Correa et al., 2017). Alternatives for wick samplers, such as suction lysimeters, should be used to avoid contamination of soil water samples.

Due to the low fitting efficiencies of the MTT models, specifically for stream water, we consider the presented MTT estimations as valuable preliminary findings. However, because of the significant risk of underestimation of MTTs using seasonally varying input signals of $\delta^{18} \mathrm{O}$ or $\delta^{2} \mathrm{H}$ (Kirchner, 2016a; Stewart et al., 2010), the long estimated transit time of up to 4 years is likely beyond the reliability of the present used method (DeWalle et al., 1997), which adds to the uncertainty of our results. Better predictions might be obtained by using more appropriate tracers for estimating transit times of several years to decades, such as tritium $\left({ }^{3} \mathrm{H}\right)$ (Cartwright et al., 2017; Stewart and Morgenstern, 2016). Despite this uncertainty, the implications of the long estimated MTT, i.e. that the sub-catchments are groundwater dominated irrespective of land use, are confirmed by the unsophisticated and more robust estimation of the $F_{y w}$. Although a longer sampling period of at least 4 years might also improve the goodness of fit of the models (McGuire and McDonnell, 2006), we believe that the low fitting efficiencies were mainly a result of the highly damped isotope signal of stream water, suggesting that the applied method and models for MTT estimation are less suitable for groundwater-dominated tropical catchments with a similarly damped stream water isotope signal. Conversely, both selected MTT models provided reasonable results for mobile soil water. However, a simpler exponential distribution model (EM) might have been equally appropriate, since the parameter range of behaviour solutions of the gamma model and the exponential piston flow model suggest that both models could be simplified to an exponential distribution model. In order to avoid over-parametrization, models with fewer parameters (in this case EM) are preferred when they provide comparable results.

\section{Conclusion}

In this study we aimed to identify the dominant water sources and flow paths in three sub-catchments with contrasting land use (i.e. natural forest, smallholder agriculture, and commercial tea and tree plantations) using mean transit time (MTT) analysis and endmember mixing analysis (EMMA) to assess the effect of land use on catchment hydrology. The low fitting efficiencies of the MTT analysis did not allow us to relate differences in estimated MTT between the catchments to land use and we were thus unable to confirm or reject our hypothesis that the natural forest sub-catchment would have a longer MTT than the catchments dominated by smallholder agriculture or commercial tea plantations. The long estimated MTT (up to 4 years) and high contributions of groundwater-related endmembers did, however, suggest that the catchments in our study area are generally groundwater dominated. These results emphasize the importance of sufficient groundwater recharge and sustainable management of groundwater resources to maintain streamflow throughout the year.

The differences in contribution of endmembers to streamflow, based on EMMA, suggest that land use could affect hydrological flow paths. We expect that the observed high contribution of precipitation and throughfall in the natural forest sub-catchment occurs as shallow subsurface flow, while precipitation in the smallholder agriculture sub-catchment could contribute to streamflow as surface run-off. Further evidence to support this statement is necessary, because surface runoff generally has a negative impact on soil fertility, erosion and sedimentation. In general, over- and under-prediction of endmember contributions, especially during the dry season and at the peak of the rainy season, indicate that the mixing models could be improved by identification of additional endmembers. The use of more appropriate methods to estimate transit times could further improve our knowledge of the hydrological behaviour of tropical catchments under different land use. Due to the weaknesses associated with both methods, there is considerable uncertainty in the estimated MTT and endmember contributions. However, supported by the young water fraction analysis, we were able to draw a reliable conclusion about the importance of groundwater during low and high flows in the different land use types. Because of the lack of data on the hydrological behaviour of African tropical montane catchments, our study provides a good baseline for future research. Due to the close linkage of forests, land use and water, such research is required to support decision making on forest protection and land management, to ensure the supply of clean and sufficient water to communities living in and downstream of tropical montane areas.

Data availability. Hydroclimatic data (discharge and precipitation) and the full isotope and trace element dataset for all study sites are available from the online database at http://fb09-pasig. umwelt.uni-giessen.de:8050/wiki/publications (Mau Earth Observatory, 2018) hosted by Justus Liebig University, Giessen, Germany. 
Supplement. The supplement related to this article is available online at: https://doi.org/10.5194/hess-22-4981-2018-supplement.

Author contributions. The study was designed by SJ, BW and LB. SJ and BW installed all instruments. SJ was in charge of field campaigns, instrument maintenance and sample collection and performed the endmember mixing analysis. BW managed the laboratory analysis. ET performed the analysis for mean transit time estimation. SJ, MR, KBB and LB prepared the manuscript.

Competing interests. The authors declare that they have no conflict of interest.

Acknowledgements. We would like to thank the Kenya Forest Service (KFS) for supporting us in conducting this study in the South-West Mau. This work was partially funded by the CGIAR program on Forest, Trees and Agroforestry led by the Centre for International Forestry Research (CIFOR). We thank the Deutsche Forschungsgemeinschaft DFG (BR2238/23-1) and the Deutsche Gesellschaft für Internationale Zusammenarbeit GIZ (grants 81195001 "Low cost methods for monitoring water quality to inform upscaling of sustainable water management in forested landscapes in Kenya") for generously providing additional support. We also appreciate the valuable feedback provided by the reviewers to improve this paper.

The article processing charges for this open-access

publication were covered by a Research

Centre of the Helmholtz Association.

Edited by: Markus Hrachowitz

Reviewed by: Francesc Gallart and three anonymous referees

\section{References}

Ali, G. A., Roy, A. G., Turmel, M.-C., and Courchesne, F.: Source-to-stream connectivity assessment through end-member mixing analysis, J. Hydrol., 392, 119-135, https://doi.org/10.1016/j.jhydrol.2010.07.049, 2010.

Asano, Y. and Uchida, T.: Flow path depth is the main controller of mean base flow transit times in a mountainous catchment, Water Resour. Res., 48, W03512, https://doi.org/10.1029/2011WR010906, 2012.

Ataroff, M. and Rada, F.: Deforestation impact on water dynamics in a Venezuelan Andean cloud forest, Ambio, 29, 440-444, https://doi.org/10.1579/0044-7447-29.7.440, 2000.

Baker, T. J. and Miller, S. N.: Using the Soil and Water Assessment Tool (SWAT) to assess land use impact on water resources in an East African watershed, J. Hydrol., 486, 100-111, https://doi.org/10.1016/j.jhydrol.2013.01.041, 2013.

Baldyga, T. J., Miller, S. N., Shivoga, W., and Gichaba, M.: Assessing the impact of land cover change in Kenya using remote sensing and hydrologic modelling, in ASPRS Annual Conference Proceedings, Denver, Colorado, 2004.
Barthold, F. K., Wu, J., Vaché, K. B., Schneider, K., Frede, H.-G., and Breuer, L.: Identification of geographic runoff sources in a data sparse region: Hydrological processes and the limitations of tracer-based approaches, Hydrol. Process., 24, 2313-2327, https://doi.org/10.1002/hyp.7678, 2010.

Barthold, F. K., Tyralla, C., Schneider, K., Vaché, K. B., Frede, H.G., and Breuer, L.: How many tracers do we need for end member mixing analysis (EMMA)? A sensitivity analysis, Water Resour. Res., 47, W08519, https://doi.org/10.1029/2011WR010604, 2011.

Barthold, F. K., Turner, B. L., Elsenbeer, H., and Zimmermann, A.: A hydrochemical approach to quantify the role of return flow in a surface flow-dominated catchment, Hydrol. Process., 31, 10181033, https://doi.org/10.1002/hyp.11083, 2017.

Beven, K. and Binley, A.: The future of distributed models: Model calibration and uncertainty prediction, Hydrol. Process., 6, 279298, https://doi.org/10.1002/hyp.3360060305, 1992.

Bewernick, T.: Mapping forest degradation in the Mau Forest Complex using NDFI time series, MS thesis, Wageningen University, Wageningen, the Netherlands, August 2016.

Binge, F. W.: Geology of the Kericho area, Ministry of Commerce, Industry and Communications, Geological Survey of Kenya, 1962.

Boy, J., Valarezo, C., and Wilcke, W.: Water flow paths in soil control element exports in an Andean tropical montane forest, Eur. J. Soil Sci., 59, 1209-1227, https://doi.org/10.1111/j.13652389.2008.01063.x, 2008.

Brown, K. W., Thomas, J. C., and Holder, M. W.: Development of a capillary wick unsaturated zone pore water sampler, United States Environmental Protection Agency, Las Vegas, USA, 1989.

Burns, D. A., McDonnell, J. J., Hooper, R. P., Peters, N. E., Freer, J. E., Kendall, C., and Beven, K.: Quantifying contributions to storm runoff through end-member mixing analysis and hydrologic measurements at the Panola Mountain Research Watershed (Georgia, USA), Hydrol. Process., 15, 1903-1924, https://doi.org/10.1002/hyp.246, 2001.

Capell, R., Tetzlaff, D., Hartley, A. J., and Soulsby, C.: Linking metrics of hydrological function and transit times to landscape controls in a heterogeneous mesoscale catchment, Hydrol. Process. 26, 405-420, https://doi.org/10.1002/hyp.8139, 2012.

Cartwright, I., Cendón, D., Currell, M., and Meredith, K.: A review of radioactive isotopes and other residence time tracers in understanding groundwater recharge: Possibilities, challenges, and limitations, J. Hydrol., 555, 797-811, https://doi.org/10.1016/j.jhydrol.2017.10.053, 2017.

Chaves, J., Neill, C., Germer, S., Neto, S. G., Krusche, A., and Elsenbeer, H.: Land management impacts on runoff sources in small Amazon watersheds, Hydrol. Process., 22, 1766-1775, https://doi.org/10.1002/hyp.6803, 2008.

Christophersen, N. and Hooper, R. P.: Multivariate analysis of stream water chemical data: The use of principal components analysis for the end-member mixing problem, Water Resour. Res., 28, 99-107, https://doi.org/10.1029/91WR02518, 1992.

Christophersen, N., Neal, C., Hooper, R. P., Vogt, R. D., and Andersen, S.: Modelling streamwater chemistry as a mixture of soilwater end-members - A step towards secondgeneration acidification models, J. Hydrol., 116, 307-320, https://doi.org/10.1016/0022-1694(90)90130-P, 1990. 
Cooper, J. D.: Water use of a tea estate from soil moisture measurements, E. Afr. Agr. Forestry J., 43, 102-121, 1979.

Correa, A., Windhorst, D., Tetzlaff, D., Crespo, P., Célleri, R., Feyen, J., and Breuer, L.: Temporal dynamics in dominant runoff sources and flow paths in the Andean Páramo, Water Resour. Res., 53, 5998-6017, https://doi.org/10.1002/2016WR020187, 2017.

Craig, H.: Isotopic variations in meteoric waters, Science, 133, 1702-1703, https://doi.org/10.1126/science.133.3465.1702, 1961.

Crespo, P., Bücker, A., Feyen, J., Vaché, K. B., Frede, H.-G., and Breuer, L.: Preliminary evaluation of the runoff processes in a remote montane cloud forest basin using Mixing Model Analysis and Mean Transit Time, Hydrol. Process., 26, 3896-3910, https://doi.org/10.1002/hyp.8382, 2012.

de Moraes, J. M., Schuler, A. E., Dunne, T., de O Figueiredo, R., and Victoria, R. L.: Water storage and runoff processes in plinthic soils under forest and pasture in eastern Amazonia, Hydrol. Process., 20, 2509-2526, https://doi.org/10.1002/hyp.6213, 2006.

DeWalle, D. R., Edwards, P. J., Swistock, B. R., Aravena, R., and Drimmie, R. J.: Seasonal isotope hydrology of three Appalachian forest catchments, Hydrol. Process., 11, 1895-1906, 1997.

Edwards, K. A. and Blackie, J. R.: Results of the East African Catchment Experiments 1958-1974, in Tropical Agricultural Hydrology, 163-200, John Wiley \& Sons Ltd., 1981.

Ekirapa, E. A. and Shitakha, F. M.: Semi detailed soil survey of the African Highland Produce Company farm, Kenya Agricultural Research Institute, Nairobi, Kenya, 1996.

Fröhlich, H. L., Breuer, L., Vaché, K. B., and Frede, H.-G.: Inferring the effect of catchment complexity on mesoscale hydrologic response, Water Resour. Res., 44, W09414, https://doi.org/10.1029/2007WR006207, 2008a.

Fröhlich, H. L., Breuer, L., Frede, H.-G., Huisman, J. A., and Vaché, K. B.: Water source characterization through spatiotemporal patterns of major, minor and trace element stream concentrations in a complex, mesoscale German catchment, Hydrol. Process., 22, 2028-2043, https://doi.org/10.1002/hyp.6804, 2008b.

Geris, J., Tetzlaff, D., McDonnell, J., and Soulsby, C.: The relative role of soil type and tree cover on water storage and transmission in northern headwater catchments, Hydrol. Process., 29, 1844 1860, https://doi.org/10.1002/hyp.10289, 2015.

Germer, S., Neill, C., Krusche, A. V., Neto, S. C. G., and Elsenbeer, H.: Seasonal and within-event dynamics of rainfall and throughfall chemistry in an open tropical rainforest in Rondônia, Brazil, Biogeochemistry, 86, 155-174, https://doi.org/10.1007/s10533007-9152-9, 2007.

Germer, S., Neill, C., Krusche, A. V., and Elsenbeer, H.: Influence of land-use change on near-surface hydrological processes: Undisturbed forest to pasture, J. Hydrol., 380, 473-480, https://doi.org/10.1016/j.jhydrol.2009.11.022, 2010.

Goldsmith, G. R., Muñoz-Villers, L. E., Holwerda, F., McDonnell, J. J., Asbjornsen, H., and Dawson, T. E.: Stable isotopes reveal linkages among ecohydrological processes in a seasonally dry tropical montane cloud forest, Ecohydrology, 5, 779-790, https://doi.org/10.1002/eco.268, 2012.

Heidbüchel, I., Troch, P. A., and Lyon, S. W.: Separating physical and meteorological controls of variable transit times in zero-order catchments, Water Resour. Res., 49, 7644-7657, https://doi.org/10.1002/2012WR013149, 2013.
Hooper, R. P.: Diagnostic tools for mixing models of stream water chemistry, Water Resour. Res., 39, 1055, https://doi.org/10.1029/2002WR001528, 2003.

Hrachowitz, M., Soulsby, C., Tetzlaff, D., Malcolm, I. A., and Schoups, G.: Gamma distribution models for transit time estimation in catchments: Physical interpretation of parameters and implications for time-variant transit time assessment, Water Resour. Res., 46, W10536, https://doi.org/10.1029/2010WR009148, 2010., 2010.

Hrachowitz, M., Soulsby, C., Tetzlaff, D., and Malcolm, I. A.: Sensitivity of mean transit time estimates to model conditioning and data availability, Hydrol. Process., 25, 980-990, https://doi.org/10.1002/hyp.7922, 2011.

ISRIC: Soil and terrain database for Kenya, version 2.0, at scale 1: 1 million (KENSOTER), 2007.

Jacobs, S. R., Breuer, L., Butterbach-Bahl, K., Pelster, D. E., and Rufino, M. C.: Land use affects total dissolved nitrogen and nitrate concentrations in tropical montane streams in Kenya, Sci. Total Environ., 603-604, 519-532, https://doi.org/10.1016/j.scitotenv.2017.06.100, 2017.

Jacobs, S. R., Weeser, B., Guzha, A. C., Rufino, M. C., ButterbachBahl, K., Windhorst, D., and Breuer, L.: Using high-resolution data to assess land use impact on nitrate dynamics in East African tropical montane catchments, Water Resour. Res., 54, 18121830, https://doi.org/10.1002/2017WR021592, 2018.

James, A. L. and Roulet, N. T.: Investigating the applicability of end-member mixing analysis (EMMA) across scale: A study of eight small, nested catchments in a temperate forested watershed, Water Resour. Res., 42, W08434, https://doi.org/10.1029/2005WR004419, 2006.

Jennings, D. J.: Geology of the Molo area, Ministry of Natural Resources, Geological Survey of Kenya, 1971.

Johnson, M. S., Lehmann, J., Selva, E. C., Abdo, M., Riha, S., and Couto, E. G.: Organic carbon fluxes within and streamwater exports from headwater catchments in the southern Amazon, Hydrol. Process., 20, 2599-2614, https://doi.org/10.1002/hyp.6218, 2006.

Katsuyama, M., Kabeya, N., and Ohte, N.: Elucidation of the relationship between geographic and time sources of stream water using a tracer approach in a headwater catchment, Water Resour. Res., 45, W06414, https://doi.org/10.1029/2008WR007458, 2009.

Kenya Water Towers Agency: Kenya Water Towers status report, Kenya Water Towers Agency, Nairobi, Kenya, 2015.

Kinyanjui, M. J.: NDVI-based vegetation monitoring in Mau Forest Complex, Kenya, Afr. J. Ecol., 49, 165-174, https://doi.org/10.1111/j.1365-2028.2010.01251.x, 2011.

Kirchner, J. W.: Aggregation in environmental systems - Part 1: Seasonal tracer cycles quantify young water fractions, but not mean transit times, in spatially heterogeneous catchments, Hydrol. Earth Syst. Sci., 20, 279-297, https://doi.org/10.5194/hess20-279-2016, 2016a.

Kirchner, J. W.: Aggregation in environmental systems - Part 2: Catchment mean transit times and young water fractions under hydrologic nonstationarity, Hydrol. Earth Syst. Sci., 20, 299328, https://doi.org/10.5194/hess-20-299-2016, 2016 b.

Koutsouris, A. J. and Lyon, S. W.: Advancing understanding in data-limited conditions: estimating contributions to streamflow across Tanzania's rapidly devel- 
oping Kilombero Valley, Hydrolog. Sci. J., 63, 197-209, https://doi.org/10.1080/02626667.2018.1426857, 2018.

Krhoda, G. O.: The impact of resource utilization on the hydrology of the Mau Hills Forest in Kenya, Mt. Res. Dev., 8, 193-200, https://doi.org/10.2307/3673447, 1988.

Maloszewski, P. and Zuber, A.: Determining the turnover time of groundwater systems with the aid of environmental tracers. 1. Models and their applicability, J. Hydrol., 57, 207-231, https://doi.org/10.1016/0022-1694(82)90147-0, 1982.

Mango, L. M., Melesse, A. M., McClain, M. E., Gann, D., and Setegn, S. G.: Land use and climate change impacts on the hydrology of the upper Mara River Basin, Kenya: results of a modeling study to support better resource management, Hydrol. Earth Syst. Sci., 15, 2245-2258, https://doi.org/10.5194/hess-15-22452011, 2011.

Mau Earth Observatory: Publications, http://fb09-pasig.umwelt. uni-giessen.de:8050/wiki/publications, last access: 23 September 2018.

McGuire, K. and McDonnell, J.: Stable isotope tracers in watershed hydrology, in Stable Isotopes in Ecology and Environmental Science, edited by: Michener, R. and Lajtha, K., Blackwell Publishing Ltd., 334-374, 2007.

McGuire, K. J. and McDonnell, J. J.: A review and evaluation of catchment transit time modeling, J. Hydrol., 330, 543-563, https://doi.org/10.1016/j.jhydrol.2006.04.020, 2006.

Mckenzie, J. M., Mark, B. G., Thompson, L. G., Schotterer, U., and Lin, P.-N.: A hydrogeochemical survey of Kilimanjaro (Tanzania): implications for water sources and ages, Hydrogeol. J., 18, 985-995, https://doi.org/10.1007/s10040-009-0558-4, 2010.

Mosquera, G. M., Lazo, P. X., Célleri, R., Wilcox, B. P., and Crespo, P.: Runoff from tropical alpine grasslands increases with areal extent of wetlands, CATENA, 125, 120-128, https://doi.org/10.1016/j.catena.2014.10.010, 2015.

Mosquera, G. M., Célleri, R., Lazo, P. X., Vaché, K. B., Perakis, S. S., and Crespo, P.: Combined use of isotopic and hydrometric data to conceptualize ecohydrological processes in a highelevation tropical ecosystem, Hydrol. Process., 30, 2930-2947, https://doi.org/10.1002/hyp.10927, 2016a.

Mosquera, G. M., Segura, C., Vaché, K. B., Windhorst, D., Breuer, L., and Crespo, P.: Insights into the water mean transit time in a high-elevation tropical ecosystem, Hydrol. Earth Syst. Sci., 20, 2987-3004, https://doi.org/10.5194/hess-20-2987-2016, $2016 \mathrm{~b}$.

Mueller, M. H., Weingartner, R., and Alewell, C.: Importance of vegetation, topography and flow paths for water transit times of base flow in alpine headwater catchments, Hydrol. Earth Syst. Sci., 17, 1661-1679, https://doi.org/10.5194/hess-17-1661-2013, 2013.

Muñoz-Villers, L. E. and McDonnell, J. J.: Runoff generation in a steep, tropical montane cloud forest catchment on permeable volcanic substrate, Water Resour. Res., 48, W09528, https://doi.org/10.1029/2011WR011316, 2012.

Muñoz-Villers, L. E. and McDonnell, J. J.: Land use change effects on runoff generation in a humid tropical montane cloud forest region, Hydrol. Earth Syst. Sci., 17, 3543-3560, https://doi.org/10.5194/hess-17-3543-2013, 2013.

Muñoz-Villers, L. E., Geissert, D. R., Holwerda, F., and McDonnell, J. J.: Factors influencing stream baseflow transit times in tropical montane watersheds, Hydrol. Earth Syst. Sci., 20, 1621-1635, https://doi.org/10.5194/hess-20-1621-2016, 2016.
Mwangi, H. M., Julich, S., Patil, S. D., McDonald, M. A., and Feger, K.-H.: Relative contribution of land use change and climate variability on discharge of upper Mara River, Kenya, J. Hydrol.-Regional Studies, 5, 244-260, https://doi.org/10.1016/j.ejrh.2015.12.059, 2016.

Nash, J. E. and Sutcliffe, J. V.: River flow forecasting through conceptual models part I - A discussion of principles, J. Hydrol., 10, 282-290, https://doi.org/10.1016/0022-1694(70)90255-6, 1970.

Neill, C., Chaves, J. E., Biggs, T., Deegan, L. A., Elsenbeer, H., Figueiredo, R. O., Germer, S., Johnson, M. S., Lehmann, J., Markewitz, D., and Piccolo, M. C.: Runoff sources and land cover change in the Amazon: An end-member mixing analysis from small watersheds, Biogeochemistry, 105, 7-18, https://doi.org/10.1007/s10533-011-9597-8, 2011.

Otte, I., Detsch, F., Gütlein, A., Scholl, M., Kiese, R., Appelhans, T. and Nauss, T.: Seasonality of stable isotope composition of atmospheric water input at the southern slopes of Mt. Kilimanjaro, Tanzania, Hydrol. Process., 31, 3932-3947, https://doi.org/10.1002/hyp.11311, 2017.

Owuor, S. O., Butterbach-Bahl, K., Guzha, A. C., Jacobs, S., Merbold, L., Rufino, M. C., Pelster, D., Díaz-Pinés, E., and Breuer, L.: Conversion of natural forest results in a significant degradation of soil hydraulic properties in the highlands of Kenya, Soil Till. Res., 176, 36-44, https://doi.org/10.1016/j.still.2017.10.003, 2018.

Prechsl, U. E., Gilgen, A. K., Kahmen, A., and Buchmann, N.: Reliability and quality of water isotope data collected with a lowbudget rain collector, Rapid Commun. Mass Sp., 28, 879-885, https://doi.org/10.1002/rcm.6852, 2014.

Roa-García, M. C. and Weiler, M.: Integrated response and transit time distributions of watersheds by combining hydrograph separation and long-term transit time modeling, Hydrol. Earth Syst. Sci., 14, 1537-1549, https://doi.org/10.5194/hess-14-1537-2010, 2010.

Rodgers, P., Soulsby, C., Waldron, S., and Tetzlaff, D.: Using stable isotope tracers to assess hydrological flow paths, residence times and landscape influences in a nested mesoscale catchment, Hydrol. Earth Syst. Sci., 9, 139-155, https://doi.org/10.5194/hess9-139-2005, 2005.

Saunders, T. J., McClain, M. E., and Llerena, C. A.: The biogeochemistry of dissolved nitrogen, phosphorus, and organic carbon along terrestrial-aquatic flowpaths of a montane headwater catchment in the Peruvian Amazon, Hydrol. Process., 20, 2549-2562, https://doi.org/10.1002/hyp.6215, 2006.

Soderberg, K., Good, S. P., O’Connor, M., Wang, L., Ryan, K., and Caylor, K. K.: Using atmospheric trajectories to model the isotopic composition of rainfall in central Kenya, Ecosphere, 4, 33, https://doi.org/10.1890/ES12-00160.1, 2013.

Soulsby, C., Rodgers, P., Smart, R., Dawson, J., and Dunn, S.: A tracer-based assessment of hydrological pathways at different spatial scales in a mesoscale Scottish catchment, Hydrol. Process., 17, 759-777, https://doi.org/10.1002/hyp.1163, 2003.

Soulsby, C., Tetzlaff, D., Rodgers, P., Dunn, S., and Waldron, S.: Runoff processes, stream water residence times and controlling landscape characteristics in a mesoscale catchment: An initial evaluation, J. Hydrol., 325, 197-221, https://doi.org/10.1016/j.jhydrol.2005.10.024, 2006.

Stewart, M. K. and Morgenstern, U.: Importance of tritium-based transit times in hydrological systems, Wiley Interdisciplinary 
Reviews: Water, 3, 145-154, https://doi.org/10.1002/wat2.1134, 2016.

Stewart, M. K., Morgenstern, U., and McDonnell, J. J.: Truncation of stream residence time: how the use of stable isotopes has skewed our concept of streamwater age and origin, Hydrol. Process., 24, 1646-1659, https://doi.org/10.1002/hyp.7576, 2010.

Timbe, E., Windhorst, D., Crespo, P., Frede, H.-G., Feyen, J., and Breuer, L.: Understanding uncertainties when inferring mean transit times of water trough tracer-based lumpedparameter models in Andean tropical montane cloud forest catchments, Hydrol. Earth Syst. Sci., 18, 1503-1523, https://doi.org/10.5194/hess-18-1503-2014, 2014.

von Freyberg, J., Radny, D., Gall, H. E., and Schirmer, M.: Implications of hydrologic connectivity between hillslopes and riparian zones on streamflow composition, J. Contam. Hydrol., 169, 6274, https://doi.org/10.1016/j.jconhyd.2014.07.005, 2014. von Freyberg, J., Allen, S. T., Seeger, S., Weiler, M., and Kirchner, J. W.: Sensitivity of young water fractions to hydro-climatic forcing and landscape properties across 22 Swiss catchments, Hydrol. Earth Syst. Sci., 22, 3841-3861, https://doi.org/10.5194/hess-223841-2018, 2018.

Windhorst, D., Waltz, T., Timbe, E., Frede, H.-G., and Breuer, L. Impact of elevation and weather patterns on the isotopic composition of precipitation in a tropical montane rainforest, Hydrol Earth Syst. Sci., 17, 409-419, https://doi.org/10.5194/hess-17409-2013, 2013.

Windhorst, D., Kraft, P., Timbe, E., Frede, H.-G., and Breuer, L.: Stable water isotope tracing through hydrological models for disentangling runoff generation processes at the hillslope scale, Hydrol. Earth Syst. Sci., 18, 4113-4127, https://doi.org/10.5194/hess-18-4113-2014, 2014. 